\title{
Do Remittances Matter for Economic Growth? ${ }^{1}$
}

\author{
Daniel DUJAVA-Marek KÁLOVEC*
}

\begin{abstract}
Remittances represent one of the most important money flows into the developing world comparable to, and often exceeding, earnings from exports of goods and services and foreign direct investments. Even though importance of remittances in poverty reduction has been documented, impact of remittances on economic growth remains under-investigated mainly due to a strong endogeneity of remittances with respect to both level and growth rates of GDP. We provide detailed look into this endogenous relationship and discuss possible instruments which can help to remedy this problem in IV-estimation. In order to establish a link between economic growth and remittances we use range of instrumental variables encompassing geographical, microeconomic-based and internal instruments. By interacting remittances with other determinants of economic growth we provide evidence that remittances are especially important source of growth in poor countries not because of low level of development per se, but because the effect of remittances on growth is stronger providing level of human capital and savings rate are low and financial markets are underdeveloped.
\end{abstract}

Keywords: remittances, economic growth, instrumental variables

JEL Classification: F24, O47

DOI: https://doi.org/10.31577/ekoncas.2020.09.01

\section{Introduction}

Remittances are defined as household income arising from temporary or permanent movement of people to different economies (IMF, 2009). Remittances usually take form of a flow of funds or goods sent from migrants back to the

\footnotetext{
* Daniel DUJAVA, corresponding author - Marek KÁLOVEC, University of Economics in Bratislava, Faculty of National Economy, Department of Economic Policy, Dolnozemská cesta 1, 85235 Bratislava, Slovakia; e-mail: daniel.dujava@mfsr.sk; marek.kalovec@mfsr.sk

${ }^{1}$ This work was supported by projects VEGA 1/0246/16 Effectiveness of Fiscal and Monetary Policy during the Business Cycle and VEGA 1/0393/16 European Union in Post-crisis PeriodMacroeconomic and Microeconomic Aspects.
} 
domestic economy to a family or friends through formal (electronic wire) or informal channels (money or goods transported across borders). A survey conducted with the intention to identify the most important drivers of remittances (Page and Plaza, 2006) describes three main incentives - altruism (family commitments, inheritance), insurance and investment. To provide more informed picture about the increasing importance of remittances, Figures $1-4$ bring together several stylized facts. ${ }^{2}$

According to World Bank data, the volume of remittances received worldwide has increased by $30 \%$ since 2010, counting 577.4 billion US dollars in 2017 . India and China are the most important receivers; however, remittances can also reach considerable volumes in wealthy countries as well - Germany and France are both among the top ten receiving countries in the world (see Figure 1).

Fig u re 1

Top 10 Absolute Recievers of Remittances in 2017 (bil. USD)

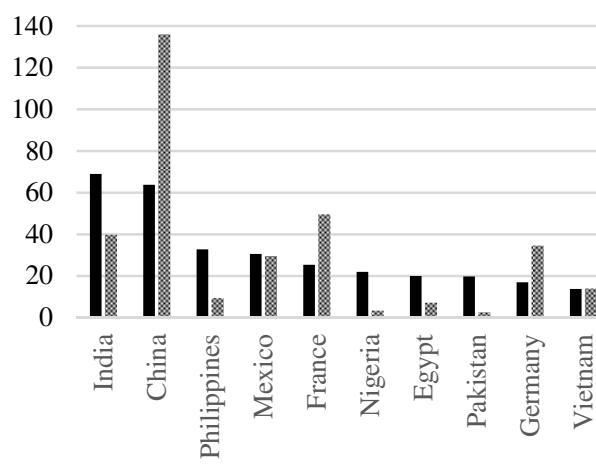

- Remittances Inflow FDI Inflow
Figure 2

\section{Remittances Received Worldwide} (\% of GDP)

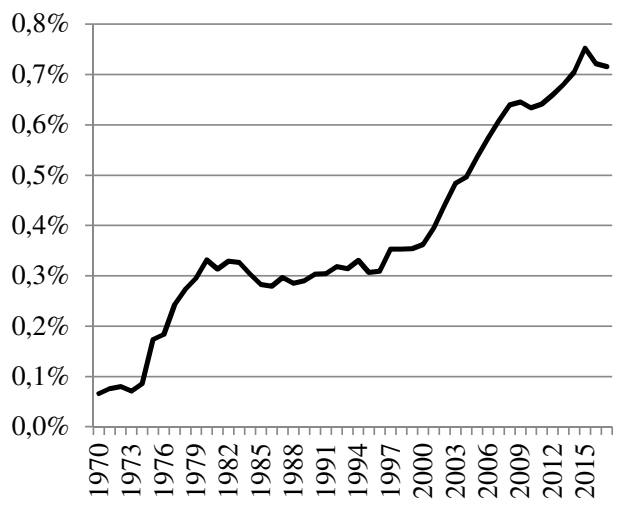

Source: World Bank; UNCTAD.

Source: World Bank.

Remittances in low- and middle-income countries (LMICs) are supposed to be driven by altruistic incentives, risk sharing, loan repayments or investments (Munzele and Ratha, 2005; Azizi, 2018). World Bank (2019) identifies additional drivers of inbound remittances, namely economic growth in certain regions

\footnotetext{
${ }^{2}$ Unless otherwise stated, all data used in this article (not just for remittances) are from World Development Indicators. This database defines remittances in the following way: 'Personal remittances comprise personal transfers and compensation of employees. Personal transfers consist of all current transfers in cash or in kind made or received by resident households to or from non-resident households. Personal transfers thus include all current transfers between resident and non-resident individuals. Compensation of employees refers to the income of border, seasonal, and other short-term workers who are employed in an economy where they are not resident and of residents employed by nonresident entities. Data are the sum of two items defined in the sixth edition of the IMF's Balance of Payments Manual: personal transfers and compensation of employees.'
} 
(EU, Russian Federation, USA), rising oil prices (Gulf Cooperation Council countries) or exchange rate fluctuations. Migration policy restrictions also determine flows of remittances in LMICs.

According to Eurostat (2019), about $60 \%$ of total outflows and inflows of remittances in the EU in recent years were intra-EU, i.e. the EU residents remit among themselves. However, as listed in Figure 1, more than $20 \%$ of total inbound personal remittances from the rest of the world to the EU come to France and about $13 \%$ to Germany (Eurostat, 2019). These remittances - originated almost exclusively as compensation of employees - based on income generated through border, seasonal and short-term work - come primarily from Switzerland and Luxembourg. This sort of remittances originates not from primarily altruistic incentives (Azizi, 2018) but rather from incentives such as loan repayments or investments. Detailed research points to predominantly personal transfers in LMICs, while in developed countries compensation of employees prevail (IMF, 2020). Albeit among top 10 receiving countries in total (Figure 1), France and Germany are not listed among top relative beneficiaries of remittances inflow due to small remittances-to-GDP ratio.

A growth rate of remittances worldwide has been steadily exceeding a growth rate of world GDP and the ratio of remittances to GDP has been therefore increasing (Figure 2). The World Development Indicators projections suggest that in 2018 remittances in current US dollars will overpass the volume of foreign direct investment in low- and middle-income countries.

Figure 3

\section{Top 10 Relative Receivers} of Remittances in 2017 (\% GDP)

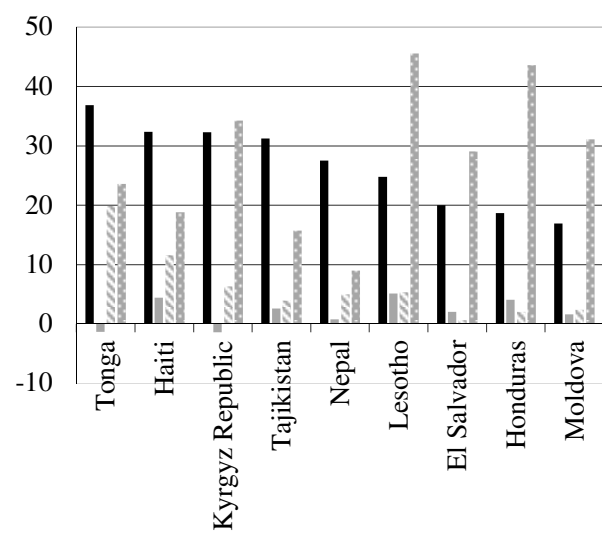

- Remittances inflow ODA

Source: World Bank.
Figure 4

Monetary Flows into the Least Developed Countries (bil. USD)

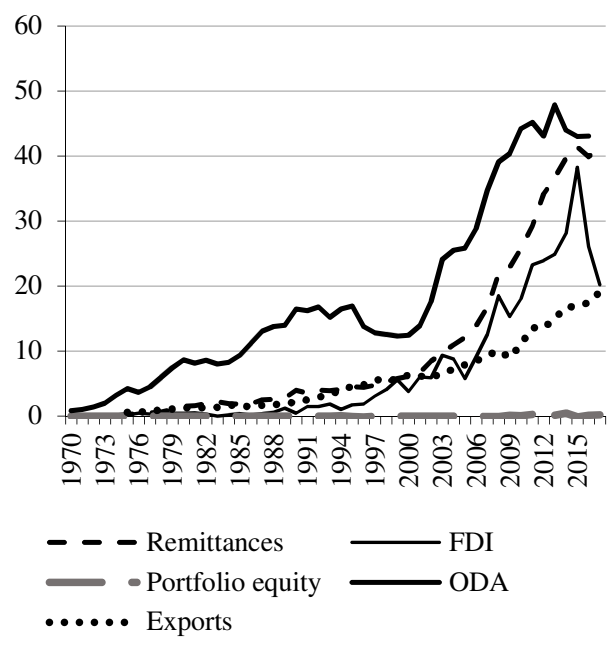

Source: World Bank. 
Importance of remittances is the highest in the least developed countries. For example, in Tonga, Haiti, Tajikistian, or Nepal, remittances already surpass monetary inflows of all other kinds (Figure 3). Recent trends suggest that remittances will soon overpass overall volume of the official development assistance (ODA) provided to the least developed countries which has been traditionally the most important foreign monetary source in the poorest economies (Figure 4). This, coupled with the fact that remittances are a more reliable sources of foreign funding than FDI due to smaller volatility and less pro-cyclical fluctuations (Gammeltoft, 2002; Ratha, 2003), underlines the importance of studying a relationship between remittances and economic growth.

The most important challenge when estimating this relationship is endogenous character of remittances. The impact of macroeconomic performance on remittances is most likely much stronger than the impact of remittances on growth (in section 2 we provide a detailed analysis of endogeneity problem). In this paper, we estimate a link between remittances and growth using set of three instruments: (i) internal instruments, i.e. lag of remittances-to-GDP ratio, (ii) microeconomically motivated instrument proposed in the working paper published by the International Monetary Fund (Gapen et al., 2009) which has not been employed by other researchers yet and (iii) new instrument based on geographical characteristics of a given country akin to instrument for trade openness developed by Romer and Frankel (1999).

Identification strategy behind is as follows: (i) we assume that there is no correlation between 5-year lag of remittances-to-GDP ratio and a residual in a growth regression, (ii) no correlation between remittances-to-GDP ratio in the rest of the world and the residual for a given country and (iii) no correlation between economic distance from other countries and the residual. Loosely speaking, this identification strategy amounts to assuming that (i) after 5 years, direct effect of remittances on growth peter out, (ii) there is no causal link between remittances-to-GDP ratio in country A and growth in country B, and (iii) there is no causal link between economic distance from other countries and economic growth other than that via remittances, investment and trade (investment and trade are controlled for). Using these three types of instruments we estimate growth regressions using panel data. We allow the effect of remittances on growth to depend on other growth determinants. In addition to finding that the effect of remittances is stronger in countries with underdeveloped financial markets we find evidence that this effect is stronger in the environment of low savings rate and low levels of human capital. On the other hand, according to our estimations, it is not low level of economic development per se what is promoting positive effect of remittances on growth. 
Next section provides literature review. In section 2 we discuss endogenous relationship between macroeconomic performance and remittances. In section 3 we introduce instrumental variables employed in the IV-estimation and also discuss inappropriateness of migration-based instruments. Empirical results can be found in section 4. Final section concludes.

\section{Literature Review}

The effect of remittances on economic development has been subject of many studies. The majority of them are based on empirical research which results in stylized facts instead of strict theoretical analysis. These studies usually conduct cross-sectional and panel data estimations of GDP growth and remittances relationship with regional dummies and fixed effects to uncover remittances' role in economic performance (Chami, Fullenkamp and Jahjah, 2005). Among the regularities uncovered by empirical research, the following stand out: a significant part of remittances is spent on consumption; these findings come from disaggregated sectoral analysis based on Greek household survey and input-output tables using variances of income and macroeconomic variables (Glytsos, 1993) and bivariate probit and multinomial logit model analysis with data gathered in Mexican household survey using multiple personal, community and economic variables (Durand et al., 1996). Some studies reveal smaller, but not negligible portion of remittances heading to savings or investments (Adams, 1991).

Driffield and Jones (2013) use three-stages least squares system estimator treating economic growth, ODA, FDIs and remittances as endogenous and conclude that remittances play a more prominent role in developing economies than in developed countries. One of the reasons, which we corroborate in this paper, is low level of financial development in poor countries. Giuliano and Ruiz-Arranz (2009) using proxies for financial development (M2, savings, foreign currency deposits, claims on the private sector) demonstrate that remittances thus help to alleviate liquidity constraints.

Remittances also directly determine the volume of consumption in domestic economy and in the short term they help to reduce poverty in developing economies. Conducting cross-country data analysis Adams and Page (2005) enrich the growth-poverty model by level of international migration and remittances and they report that a $10 \%$-increase in the share of remittances on GDP reduces the poverty rate by $1.6 \%$ (poverty measured as a number of people living from less than USD 1 per day). Similar conclusions have been reached by other studies showing remittances as important part of household livelihood strategies. However, this source of income might be unreliable (Munzele and Ratha, 2005). By using data of money 
transfer costs and results of household surveys, Freund and Spatafora (2005) reveal that (i) the stock of migrants and size of economy stand out as main drivers of remittances; and (ii) informal remittances may equal about $35-75 \%$ of official flows.

Billmeier and Massa (2009) documented on panel regression of 17 Middle East and Central Asian countries that remittances together with institutions contribute to development of market capitalization, especially in countries which are not significantly equipped with natural resources. Some surveys show that remittances are also a source of funding for small businesses and thus improve access to capital (Ratha, 2003) while others identified positive effects on human capital when remittances reduce the dropout rates of children from schools and households even spend more on private tuition (Ratha, 2006).

Remittances also determine social development - health, education, entrepreneurship and well-being. Studies confirm the positive relationship between remittances and health, especially of children. Households receiving remittances invest more in healthcare and education of children. Cross-sectional data analysis of remittances with interaction between historical migration patterns and household characteristics as instruments comes to conclusion that children in migrant households complete significantly more years of schooling (on link between remittances and human capital see Ratha (2013); for remittances' impact on schooling see Hanson and Woodruff (2003)).

There is significantly less clarity about the long-term effects on economic development. These effects have been investigated by two types of remittancesgrowth studies: traditional cross-country analysis using cross-section or panel data and detailed estimations of channels through which remittances affect economic growth in individual countries. The results of empirical studies are mixed. By using a standard cross-country growth regression framework some studies find that remittances have no significant effect (IMF, 2005). Other studies report even a negative impact (Chami, Fullenkamp and Jahjah, 2005; Gapen et al., 2009).

However, other research identifies positive effect of remittances on growth in certain developing countries by vector autoregression framework (Siddique, Selvanathan and Selvanathan, 2011) or in panel settings (Kiio, Soi and Buigut, 2014). Several studies document that the effect of remittances on growth depends on other determinants. Durand et al. (1996) run multinomial logit model on microeconomic data on Mexican migrants and find that remittances are more likely to be spent on production (as opposed to spending on consumption or housing) if migrants are well educated, own land, a business, or a home. Catrinescu et al. (2009) and Giuliano and Ruiz-Arranz (2009) use country-level panel data incorporating institutional variables and find that the effect of remittances is stronger in countries with higher institutional quality (Catrinescu et al., 2009) and lower financial development (Giuliano and Ruiz-Arranz, 2009). 


\section{Deeper Look into Endogeneity of Remittances and Macroeconomic Performance}

One of the most important obstacles in the investigation of the impact of remittances on economic growth is endogenous nature of remittances-to-GDP ratio with respect to economic outcomes. Assuming that the true impact of remittances on economic activity is indeed positive, it is straightforward to identify several channels which can possibly bias OLS estimates downwards. We illustrate these channels with simple regressions using cross-sectional and panel data (to save on space, we report regression results in the Annex). We would like to emphasize that these regressions intend to inform about partial correlations and not to describe casual relationships. In particular:

1. Low GDP per capita in developing countries (and even a periods of slow growth) promote emigration. Since migrants tend to send part of their earnings to their home country, this creates a negative statistical relationship between remittances and measures of economic activity.

Figure 5

Logs of GDP per capita and Remittances-to-GDP Ratio in 2017

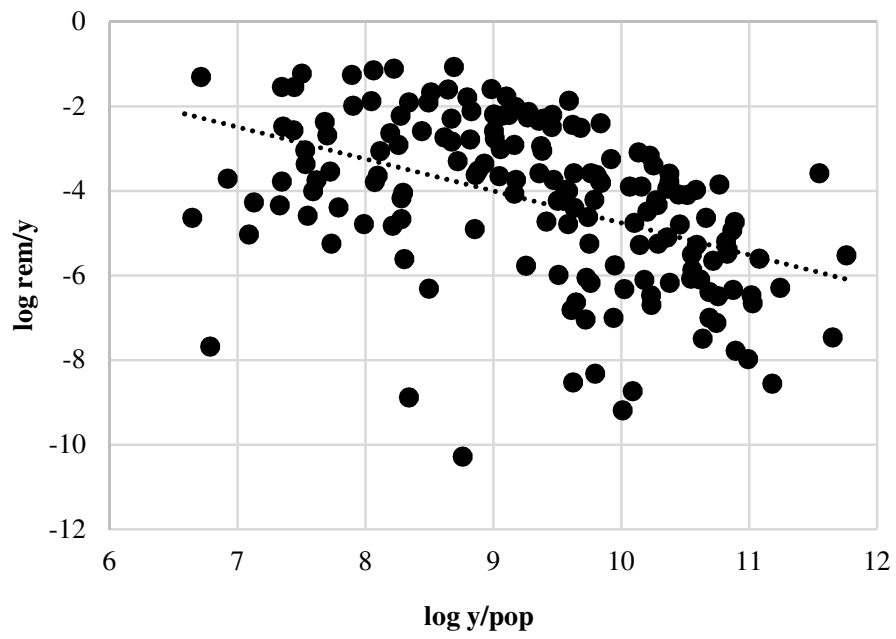

Source: World Bank; authors' calculations

2. This is illustrated in Figure 5 contrasting logs of GDP per capita (in purchasing power parity in current prices) and remittances-to-GDP ratio in 2017. Regressing log of rem/y on log of $y /$ pop yields statistically significant beta equal to -0.755 (see regression 1 in Table A1 in the Annex). These results are confirmed using panel data. A relationship between growth rates of GDP per capita and changes in remittances-to-GDP ratio are less clear. Nevertheless, using panel-data 
settings with country-specific and time-specific fixed effects produces significant negative estimate of beta equal to -0.822 (column 4 in Table A1). ${ }^{3}$

3. Furthermore, if altruistic considerations are a primary motive creating a flow of remittances (note that remittances mostly constitute flow of money between family members), negative economic outcome in home country can boost remittances even if number of migrants is held constant.

4. When investigating a link between remittances and economic growth, it is natural to use remittances-to-GDP ratio $\mathrm{rem} / \mathrm{y}$ as an explanatory variable. It is important to note that behavior of rem/y is different than that of other ratios commonly used in growth regressions, for example investment-to-GDP ratio $i / y$.

Consider an exogenous increase in output $y$ (for example due to technological progress) in a home country. For a typical household, higher output leads to increased income. This represents a greater pool of resources which can be divided between consumption and savings, which are turned into investment. Under homothetic preferences (usual assumption in growth models), average propensity to save is independent of level of output, therefore $i / y$ remains unchanged (seminal work in neoclassical growth theory even assumed that $i / y$ is constant and exogenously given; Solow, 1956).

On the other hand, pool of resources from which remittances are created is determined by output in host country which is largely independent from development in home country (this is doubly true if home country is small developing economy and host country is a large advanced economy such as United States or Germany). Therefore, increase in domestic $y$ does not automatically lead to increase in rem which creates negative relationship between $y$ and $\mathrm{rem} / \mathrm{y} .{ }^{4}$ Note that when regressing $\Delta \log \mathrm{rem} / \mathrm{y}$ on $\Delta \log y / \mathrm{pop}$ in the presence of countryspecific and time-specific fixed effect, estimated coefficient is not significantly different from unity (see regression 4 in Table A1), which indicates that this effect might be strong. ${ }^{5}$

\footnotetext{
${ }^{3}$ In panel estimations we use data spanning 1971 - 2017. To test whether data on remittances suffer from potential structural or methodological breaks we focused on countries for which data are available beginning 1971. For each year we have calculated cross-country variance of log of $\mathrm{rem} / \mathrm{y}$ and tested for presence of structural break in the variance. Changes in variance would indicate for sample improvement in data collection or in precision of data processing. No structural breaks were detected.

${ }^{4}$ Barro and Lee (1994) speculated that this 'mechanical' effect is responsible for a perceived negative relationship between ratio of government expenditures to GDP $g / y$ and output $y$ in their regressions.

${ }^{5}$ We estimated analogous models (not reported here) using investment-to-GDP ratio $(i / y)$ and ratio of government consumption to GDP $(g / y)$ instead of remittances-to-GDP ratio. In case of $i / y$, $\beta_{i n v}=0.086$ is significant on $5 \%$ level, in case of $g / y, \beta_{\text {gexp }}=-0.055$ is significant on $1 \%$ level. Positive sign of $\beta_{\text {inv }}$ and much smaller magnitude of $\beta_{\text {gexp }}$ signify differences in behaviour of $\mathrm{rem} / \mathrm{y}$, $i / y$ and $g / y$.
} 
5. Failing to control for the size of an economy can also be a source of bias. Assume a growth regression examining the impact of remittances-to-GDP ratio on GDP per capita controlling for trade openness. Regression coefficient on rem/y is expected to provide an information about the effect of an increase in $\mathrm{rem} / \mathrm{y}$ on output if control variables including trade openness are held constant.

However, in large economies (where size is measured by area or by population) larger portion of migration takes place within a given country. Whereas Slovak citizens tend to migrate to different European countries, citizens of Hubei province move to different provinces within China.

As argued by Romer and Frankel (1999), larger countries have more scope for within-country trade which can be a source of economic growth. If the effect of the country size on GDP per capita is positive (holding trade openness constant) and correlation between the country size and $\mathrm{rem} / \mathrm{y}$ is negative, omitting the size of the economy from the growth regression tend to bias regression coefficient on rem/y downwards.

To quantify a relationship between country size and remittances-to-GDP ratio, we run set of regressions reported in Table A2 in the Annex. According to our results, doubling the area of a given country holding population density constant decreases remittance-to-GDP ratio by approximately $15 \%\left(2^{0.044-0.258}=0.850\right.$ based on the estimates in regression 6 , the estimates in regression 3 are very similar). ${ }^{6}$

6. In addition to above mentioned sources of endogeneity, measurement error is a common problem in any research of remittances. Official data include only banking transactions, whereas cash transfers can amount significant portion of a true volume. The World Bank notes that the data on remittances are often not officially reported and the data on migrants in various destinations are incomplete and there is no way to capture remittances flowing through unrecorded informal channels.

7. However, as argued by Giuliano and Ruiz-Arranz (2009), if remittances are profit-driven, for example if recipients invest on behalf of migrants, correlation of remittances and economic growth can be positive. They illustrate the argument by correlating cyclical components of output and remittances for developing countries. In most of the sample, they find positive correlation. We regress level

\footnotetext{
${ }^{6}$ Table A2 reports regression of $\log$ of remittances-to-GDP ratio on measures of the size of the economy. Both $\log$ of population $(\log p o p)$ and $\log$ of area $(\log$ area $)$ are used. Regressions $1-3$ in Table A2 are based on cross-section of countries in 2017. Although there is a negative relationship between the country size and remittances-to-GDP ratio (regressions 1 and 2), due to multicollinearity between these two measures it is not possible to distinguish which of these two is more important (correlation of $\log$ pop and $\log$ area is 0.869 in 2017). Therefore, we re-estimate these relationships using panel data. Since there is no time variation in countries' area, we do not use country-specific time effects. Time-specific dummy variables are still included. Regression 6 indicates that country's area is an appropriate measure when assessing link between the size of the economy and remittances-to-GDP ratio.
} 
of remittances-to-GDP ratio on growth rate of GDP per capita using both cross sectional data and panel data (see Table A3 in the Annex). We also find significant positive partial correlation between economic growth and remittances. ${ }^{7}$

\section{Looking for Instruments}

Above discussion should make it clear that finding suitable instruments for remittances is of a paramount importance when examining their effect on the macroeconomic performance. Several types of instruments have been used by the literature, in particular internal, migration-based and microeconomic instruments. We discuss each of these and also suggest geographical instruments constructed using a gravity equation on bilateral remittances data akin to Romer and Frankel (1999).

Internal instruments: Using a lagged value of remittances is the most straightforward way of instrumenting based on the assumption of no correlation between a lag of remittances and a residual in a growth regression. Since remittances can also be driven by investment motives, there is a possible positive partial relationship between remittances-to-GDP ratio and expected growth. As long as expectations of households are on average fulfilled, short lag of remittances might not solve endogeneity problem. We address this issue by using five-year lags.

Migration-based instruments: IMF (2005) uses dummy variable for common language (official or spoken) with the most important host country. Instead of common language indicator, Faini (2006) uses geographical distance. However, such variables are not time variant and therefore cannot be used in panel settings with country-specific fixed effects. To overcome a problem of time invariance, WB (2006) multiplies inverse of distance from the most important host country by measures of performance (GDP per capita, GDP growth rate, unemployment rate). Alternatively, another instrument was constructed based on top five OECD destination countries. The most important problem with these instruments is a fact that countries are rarely linked solely by remittances flows. Instead, it is reasonable to assume that in most cases pairs of countries between which remittances flows are significant will also be linked via FDI and/or trade relationships. Therefore, identification assumption of no correlation between instrument and a residual in growth regression is likely to be violated.

\footnotetext{
${ }^{7}$ Even though cross-sectional relationship estimated in regression 1 in Table A3 is positive, it is not statistically significant. One of the possibilities is that positive relationship between remittances-to-GDP and growth is caused by omitting level of GDP. Even though unconditional convergence is not proved in the data, convergence effect can create faster growth in poorer countries and less developed countries are typical recipients of remittances. Therefore, we control for lag of level of GDP per capita in regressions 3 and 4 . As expected, coefficient on $\Delta \log g d p / p o p$ is reduced but is still highly significant.
} 
To explore this issue, for each pair of countries we calculated remittances-toGDP ratio $\frac{r e m_{i, j, t}}{y_{i, t}}$, ratio of FDI stock to GDP $\frac{f d i_{i, j, t}}{y_{i, t}}$ and ratio of total exports to GDP $\frac{\text { exports }_{i, j, t}}{y_{i, t}}$ ( $j$ being source country of remittances/FDI or importing country). ${ }^{8}$ Subsequently, for each remittances-receiver $i$ we quantified correlations between geographical structure of remittances, FDI and exports earnings, i.e. $\operatorname{corr}\left(\frac{\operatorname{rem}_{i, j, t}}{y_{i, t}}, \frac{f d i_{i, j, t}}{y_{i, t}}\right)$ and $\operatorname{corr}\left(\frac{\operatorname{rem}_{i, j, t}}{y_{i, t}}, \frac{\text { exports }_{i, j, t}}{y_{i, t}}\right)$. In 2012, average correlation between structure of remittances and of FDI stock was 0.384. Correlation between structure of remittances and trade structure was even higher, $\operatorname{corr}\left(\frac{\text { rem }_{i, j, t}}{y_{i, t}}, \frac{\text { exports }_{i, j, t}}{y_{i, t}}\right)=0.599$. Figures 6 and 7 depict full distributions of above mention correlations in 2012. High correlations suggest that countries linked by remittances flows are also likely to be linked by other channels. Therefore, we do not use migration-based instruments in our analysis.

Figure 6

Figure 7

Distribution of Correlations between Geo. Distribution of Correlations between Structure of Remittances and FDI Stock Geo. Structure of Remittances and in 2012 (based on bilateral data)

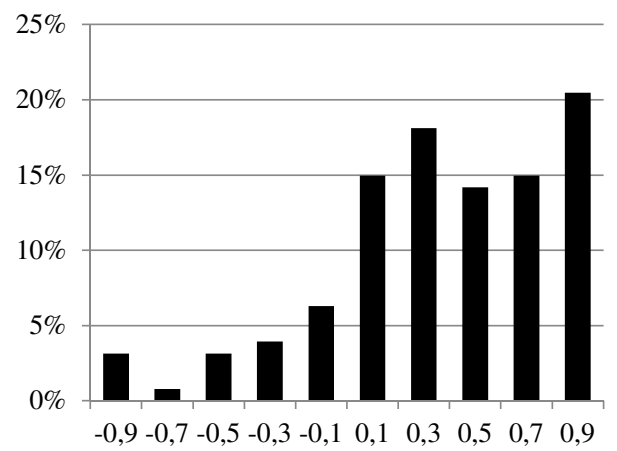
Exports in 2012 (based on bilateral data)

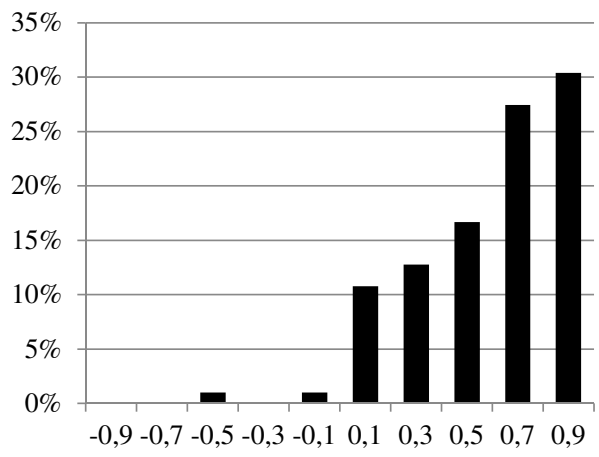

Source: World Bank; UCTAD; authors' calculations.

Source: World Bank; UCTAD; authors' calculations.

Microeconomic instruments: Gapen et al. (2009) suggest using cost of money transfers as an instrument. Since microeconomic data on such costs are limited, ${ }^{9}$ authors use remittances-to-GDP ratio in the rest of the world as proxy. We follow these authors and instrument $\log r e m_{i, 1} / y_{i, t}$ by

\footnotetext{
${ }^{8}$ Bilateral data on remittances are from the World Bank, data on FDI were obtained from UNCTAD, data on trade are from the UN Comtrade Database.
} 


$$
\log \left(\mathrm{rem}_{i, t} / y_{i, t}\right)^{R W}=\log \left[\frac{\left(\sum_{j=1}^{N} \mathrm{rem}_{j, t}\right)-\mathrm{rem}_{i, t}}{\left(\sum_{j=1}^{N} y_{j, t}\right)-y_{i, t}}\right]
$$

where $\mathrm{N}$ is a number of countries. Identification strategy behind this instrument is based on the idea that there is no causal link between a remittances-to-GDP ratio in country $j$ and the growth in country $i$.

Geographical instruments: In the well-known paper Jeffrey A. Frankel and David Romer (Romer and Frankel, 1999) examine the effect of trade on economic growth and treat endogeneity of trade-to-GDP ratio in the following way: In the first step, a bilateral gravity equation is estimated in which trade-to-GDP ratio is regressed on a set of variables capturing geographical and cultural distance between each pair of countries. Subsequently, fitted values are used to compute constructed trade-to-GDP ratio in which only variation due to geographical factors is reflected. Assuming that international trade is the only channel via which distance from other countries influences macroeconomic performance, constructed trade-to-GDP ratio can be used as an instrument.

We treat remittances in a similar way. We assume that there is no correlation between the residual in the growth equation and economic distance from other countries. Note that we already do control for trade openness. Using bilateral panel data on remittances spanning years 2010 - 2017 (68 486 observations, data were obtained from the World Bank Database) we estimate the following model:

$$
\log \operatorname{rem}_{i, j, t} / y_{i, j, t}=\mathbf{X}_{i, j, t} \beta+\epsilon_{i, j, t}
$$

where $\mathrm{X}_{i, j, t}$ is a matrix of geographical determinants of remittances. We include 43 explanatory variables, ${ }^{10}$ in particular:

- population and area of both countries and their squares,

- dummies for (i) contingency, (ii) same official language, (iii) same spoken language, (iv) common colonizer, (v) being historically same country,

- log of geographical distance and its square,

- interaction of each variable with contingency dummy and geographical distance,

- $\log$ of world population.

Estimation results are reported in Table 1. Despite low number of covariates relative to number of observations, the model fits data relatively well $\left(R^{2}=0.40\right)$

\footnotetext{
${ }^{9}$ World Bank provides estimates of costs of remittances in the Remittances Prices Worldwide Database. However, only data since 2011 are available. According to WB (2018), between 2010 and 2015 cost of sending 200 US dollars decreased approximately from 9 to 7 US dollars and have remained constant since then.

${ }^{10}$ All geographical variables are from the CEPII database.
} 
and Figure 8 plots fitted to actual values. To simplify interpretation, $\log n_{j}, \log n_{i}$, $\log$ area $_{j}, \log$ area $_{i}$ and log distance have been demeaned. Therefore, for example, average marginal elasticity of remittances on population of sending country is $d\left(\log r e m_{i, j, t} / y_{i, j, t}\right) / d \log n_{i}=0.634$ (for non-contingent countries). Note that remittances increase with the size of sending country $j$ and decrease with the size of receiving country $i$. Common language promotes remittances (even though the effect of spoken language is hardly significant in case of contingent country; $0.674-0.739=0.065)$. Having a common history as a single political unity also promote flows of remittances. The effect of common colonizer is not so straightforward and negative signs in the second and third column remain slightly puzzling. However, note that having common colonizer increases probability of having common language, therefore, interpreting coefficients corresponding to common colonizer in ceteris paribus fashion can be misleading.

T a ble 1

\section{Estimation Results of Gravity Equation}

\begin{tabular}{|c|c|c|c|}
\hline & beta & int. w/contingency & int. w/log distance \\
\hline \multirow[t]{2}{*}{$\log n_{j}$} & $0.634 * * *$ & $0.389 * * *$ & $-0.215^{* * *}$ \\
\hline & $(0.010)$ & $(0.057)$ & $(0.012)$ \\
\hline \multirow[t]{2}{*}{$\left(\log n_{j}\right)^{2}$} & $-0.039 * * *$ & $-0.028^{*}$ & $-0.029 * * *$ \\
\hline & $(0.003)$ & $(0.015)$ & $(0.003)$ \\
\hline \multirow[t]{2}{*}{$\log$ area $_{j}$} & $0.063 * * *$ & $0.386^{* * *}$ & $0.246^{* * * *}$ \\
\hline & $(0.009)$ & $(0.051)$ & $(0.011)$ \\
\hline \multirow[t]{2}{*}{$\left(\log \operatorname{area}_{j}\right)^{2}$} & $0.037 * * *$ & $0.064 * * *$ & $0.029 * * *$ \\
\hline & $(0.002)$ & $(0.009)$ & $(0.002)$ \\
\hline \multirow[t]{2}{*}{$\log n_{i}$} & $-0.089 * * *$ & $-0.123^{*}$ & $0.064 * * *$ \\
\hline & $(0.011)$ & $(0.065)$ & $(0.013)$ \\
\hline \multirow[t]{2}{*}{$\left(\log n_{i}\right)^{2}$} & $0.104 * * *$ & $-0.074 * * *$ & $-0.041^{* * *}$ \\
\hline & $(0.004)$ & $(0.019)$ & $(0.005)$ \\
\hline \multirow[t]{2}{*}{$\log$ area $_{i}$} & $-0.380 * * *$ & $-0.253^{* * *}$ & $0.028 * *$ \\
\hline & $(0.009)$ & $(0.060)$ & $(0.011)$ \\
\hline \multirow[t]{2}{*}{$\left(\log \text { area }_{i}\right)^{2}$} & $-0.0 .082 * * *$ & $0.079 * * *$ & $0.032 * * *$ \\
\hline & $(0.003)$ & $(0.016)$ & $(0.003)$ \\
\hline \multirow[t]{2}{*}{ same official language } & $0.843 * * *$ & $0.654 * * *$ & $0.583^{* * * *}$ \\
\hline & $(0.054)$ & $(0.198)$ & $(0.062)$ \\
\hline \multirow[t]{2}{*}{ same spoken language } & $0.674 * * *$ & $-0.739 * * *$ & -0.060 \\
\hline & $(0.053)$ & $(0.188)$ & $(0.059)$ \\
\hline \multirow[t]{2}{*}{ common colonizer } & $0.591 * * *$ & $-1.755^{* * * *}$ & $-0.685^{* * *}$ \\
\hline & $(0.050)$ & $(0.161)$ & $(0.053)$ \\
\hline \multirow[t]{2}{*}{ same country } & $0.482 * *$ & $0.535^{* *} *$ & 0.145 \\
\hline & $(0.208)$ & $(0.173)$ & $(0.102)$ \\
\hline \multirow[t]{2}{*}{$\log$ distance } & $-1.536^{* * * *}$ & $-2.130 * * *$ & - \\
\hline & $(0.020)$ & $(0.243)$ & - \\
\hline \multirow[t]{2}{*}{$(\log \text { distance })^{2}$} & $-0.293 * * *$ & $-0.293^{* * *}$ & - \\
\hline & $(0.013)$ & $(0.056)$ & - \\
\hline \multirow[t]{2}{*}{ contingency } & $-1.402 * * *$ & - & - \\
\hline & $(0.303)$ & - & - \\
\hline \multirow[t]{2}{*}{$\log n_{\text {world }}$} & $-5.900 * * *$ & - & - \\
\hline & $(0.389)$ & - & - \\
\hline \multirow[t]{2}{*}{ constant } & $121.416^{* * *}$ & - & - \\
\hline & $(8.828)$ & - & - \\
\hline
\end{tabular}

Note: Standard errors are in parentheses; $*$, **, *** denotes significance level of $10 \%, 5 \%$ and $1 \%$ respectively. Source: Authors' estimation. 
Subsequently, we follow Romer and Frankel (1999) and compute (log of) constructed remittances-to-GDP ratio for each receiving country $i$ as:

$$
\log \left(\operatorname{rem}_{i, t} / y_{i, t}\right)^{G E O}=\log \left(\sum_{j=1}^{N} \exp \left[\log \frac{\text { rem }_{i, j, t}}{y_{i, j, t}}\right]^{\text {fitted }}\right)
$$

This variable is used as an instrument. Observe that because population of each country changes over time, above methodology produces time-variant instrument which can be used in panel setting.

Figure 8

\section{Goodness of Fit of Gravity Equation}

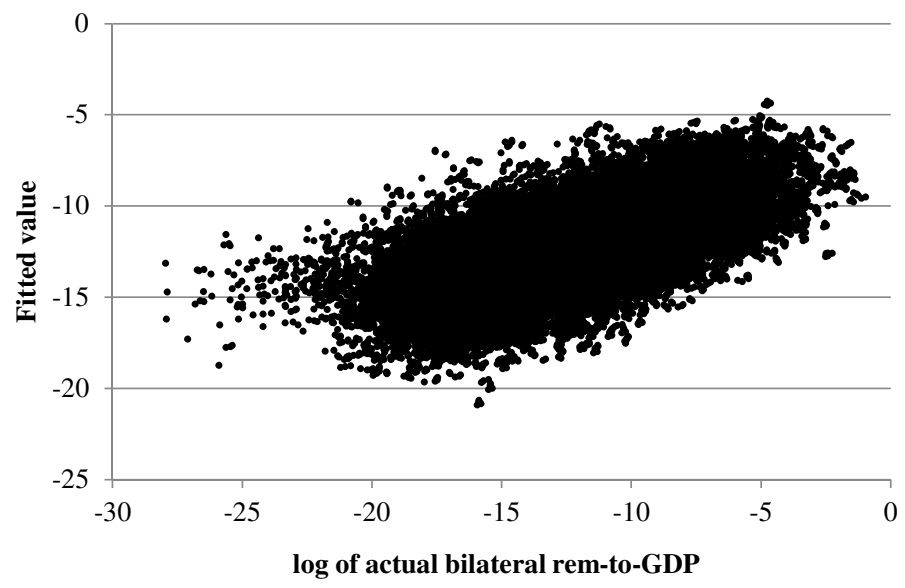

Source: World Bank; authors' calculations.

\section{Empirical Results}

Our primary interest is in estimating a conditional effect of remittances-to-GDP ratio on the macroeconomic performance using panel data with fixed country-specific effects. Several estimation strategies are available.

One possibility is splitting the sample either exogenously (e.g. on subsample of developed vs. developing countries) or endogenously. In case of endogenous splitting, estimation involves identifications of one or more thresholds. Such method has been developed for IV-estimation for cross-sectional data (Caner and Hansen, 2004) and for OLS in non-dynamic panel setting (Hansen, 1997). STATA and MATLAB codes for implementing these methods are available. However, our approach requires IV-estimation in panel setting. Seo and Shin (2016) develop a methodology for estimating models with endogenous thresholds in dynamic 
panels, but to our knowledge, this was not implemented in standard software packages yet. Therefore, we turn to another possibility which consists of using interaction terms. We estimate the following equation:

$$
\Delta \log y_{i, t} / \text { pop }_{i, t}=\gamma_{1} \log \mathrm{rem}_{i, t} / y_{i, t}+\gamma_{2} \log \mathrm{rem}_{i, t} / y_{i, t} \times z_{i, t}+\mathbf{X}_{i, t} \beta+\mu_{i}+\delta_{t}+\epsilon_{i, t}
$$

where $z_{i, t}$ is conditioning term, $\mu_{i}$ and $\delta_{t}$ are country-specific and time-specific fixed effects and $\mathbf{X}_{i, t}$ is a matrix of covariates including:

- 5-year lag of GDP per capita,

- human capital per capita $\log h_{i, t}$ from Penn World Tables 9.0 (data for years 2015 - 2017 are not available, therefore linear extrapolations were used),

- savings rate $s_{i, t}$ (being equal to share of gross fixed capital formation on GDP),

- trade openness open $_{i, t}$,

- inflation rate $\pi_{i, t}$,

- quality of institutions inst $_{i, t}$ proxied by index of political stability and absence violence from World Governance Indicators (WGI; until 2002 WGI were computed biannually, values for years 1997, 1999 and 2001 were therefore computed as linear interpolations; index is on the scale from -2.5 to +2.5 , higher values indicate better institutions),

- ratio of banking credit to GDP credit $_{i, t}$,

- $\log$ of population $\log n_{i, t}$ (never used as conditioning variable),

- $\log \left(g_{n}+g_{y}+\delta\right.$ ) based on neoclassical growth model (see Mankiw, Romer and Weil, 1992; Solow, 1956), $g_{n}$ being population growth rate, $g_{y}$ being rate of technological progress calibrated to $2 \%$ and $\delta$ being depreciation rate calibrated to $6 \%$.

Inclusion of lagged GDP per capita, human capital, $\log (n+g+\delta)$ and savings rate is based on standard neoclassical growth model as referenced above. We include trade openness, inflation rate, index of political stability and absence of violence and ratio of banking credit to GDP to control for four most important determinants of aggregate productivity - integration in world economy, economic policy, quality of institutions and financial development. Another important determinant - geography (including climate, soil quality, natural resources and so on) - is captured by country-specific fixed effect $\mu_{i}$. Population is included to control for within-country trade as explained above.

We use two kinds of conditioning terms:

1. We interact remittances-to-GDP ratio with each covariate separately (excluding population). Results are reported in Table 2.

2. For each covariate $x$ we construct dummy variable $D_{i, t}^{x}$ equal to zero, if value of $x$ is below the threshold value and equal to one otherwise. By default, we use median values as thresholds. However, for certain variables we find that using different threshold produces more informative results (we have experimented 
with 10th, 25th, 75th and 90th percentile as thresholds). In particular, for savings rate we use 10th percentile as the threshold, for credit-to-GDP ratio we use 25th percentile. We interact remittances-to-GDP ratio with these terms separately. Results are reported in Table 3.

As explained in section 3, ratio of remittances to GDP is instrumented by:

- lagged remittances-to-GDP ratio,

- remittances-to-GDP ratio in the rest of the world,

- constructed remittances-to-GDP ratio based on bilateral gravity equation.

Due to endogenous nature of $\mathrm{rem}_{i, t}$ it is also necessary to instrument interaction term remi,t $y_{i, t} \times z_{i, t}$. We use products of $z_{i, t}$ and each above mentioned instrument.

In each regression we use only a single conditioning term. Interacting log $\mathrm{rem} / \mathrm{y}$ with multiple terms creates need to introduce additional instruments and introduces multicollinearity what reduces precision of the estimation.

Our dataset consists of panel spanning 1998 - 2017. We aggregate data to five-year frequency and all continuous covariates which interact with $\log r e m_{i, t} / y_{i, t}$ are demeaned so that estimated coefficients can be interpreted as average effects (see Wooldridge, 2001).

Presence of multiple instruments enables to test their endogeneity through Sargan-Hansen test. $P$-values are reported in Tables 2 and 3. We decided to proceed with our estimations despite low $p$-values which suggest that some of our instruments are not strictly exogenous. Test of overidentifying restrictions does not permit to identify which instrument does not satisfy exogeneity condition, therefore, we reestimated models in Tables 2 and 3 using only lagged remittances-to-GDP and remittances-to-GDP in the rest of the world as instruments. $P$-values of Sargan-Hansen test increase and only in 4 out of 15 we detect $p$-value lower than 1 percent. This suggest that it is geography-based instrument which is endogenous.

However, this is not supported by economic theory and analogous instruments developed by Romer and Frankel (1999) are accepted as the best way of instrumenting for trade openness (see for example Rodrik, Subramanian and Trebbi, 2004). First-stage regressions are reported in the Appendix (Tables A4 and A5). Possible problem with estimations in 2 and 3 is Hurwicz-Nickell bias arising as a consequence of dynamic nature of our panel model combined with the presence of country-specific fixed effects. Possible remedy consists in estimating model via GMM methods based on Arellano and Bond (1991) or Blundell and Bond (1998).

However, Sargan test rejects validity of instruments required by these methods (after differencing, deeper lags of dependent variable are not exogenous). Also, 
note that Barro (2015) uses Monte-Carlo simulation to demonstrate that Allerano-Bond estimator sharply overestimates the convergence rate in growth regressions whereas Blundell-Bond estimator sharply underestimated rate of convergence. Therefore, estimates produced by these two methods cannot be considered unbiased. This is why we decided to restrict our methodology to standard panel IV-estimation.

Table 2

Estimation Results I. - Interacting Remittances-to-GDP Ratio with other Covariates

\begin{tabular}{|c|c|c|c|c|c|c|c|c|}
\hline & (1) & (2) & (3) & (4) & (5) & (6) & (7) & (8) \\
\hline $\log \mathrm{rem} / \mathrm{y}$ & $\begin{array}{l}0.063 * * \\
(0.024)\end{array}$ & $\begin{array}{l}0.040 \\
(0.105)\end{array}$ & $\begin{array}{l}0.092 * * * \\
(0.030)\end{array}$ & $\begin{array}{l}0.059 * * \\
(0.023)\end{array}$ & $\begin{array}{c}0.057^{*} \\
(0.031)\end{array}$ & $\begin{array}{l}-0.033 \\
(0.077)\end{array}$ & $\begin{array}{c}0.048 * \\
(0.028)\end{array}$ & $\begin{array}{l}0.068 * * \\
(0.032)\end{array}$ \\
\hline $\log y_{t-1} / n_{t-1}$ & $\begin{array}{l}-0.234 * * * \\
(0.052)\end{array}$ & $\begin{array}{l}-0.228 * * * \\
(0.068)\end{array}$ & $\begin{array}{l}-0.226^{* * * *} \\
(0.055)\end{array}$ & $\begin{array}{l}-0.223 * * * \\
(0.052)\end{array}$ & $\begin{array}{l}-0.231 \text { *** } \\
(0.051)\end{array}$ & $\begin{array}{l}-0.222 * * * \\
(0.051)\end{array}$ & $\begin{array}{l}-0.244 * * * \\
(0.054)\end{array}$ & $\begin{array}{l}-0.188^{* * * *} \\
(0.065)\end{array}$ \\
\hline $\log h$ & $\begin{array}{l}0.096 \\
(0.186) \\
0.640 * * *\end{array}$ & \begin{tabular}{|l|}
0.067 \\
$(0.184)$ \\
$0.637 * * *$
\end{tabular} & $\begin{array}{l}-0.256 \\
(0.293) \\
0.559 * * *\end{array}$ & $\begin{array}{c}0.068 \\
(0.188) \\
-0.114\end{array}$ & \begin{tabular}{|l}
0.072 \\
$(0.192)$ \\
$0.632 * * *$
\end{tabular} & \begin{tabular}{|l}
0.088 \\
$(0.182)$ \\
$0.749 * * *$
\end{tabular} & $\begin{array}{l}-0.029 \\
(0.220) \\
0.665^{* * *}\end{array}$ & $\begin{array}{l}0.146 \\
(0.228) \\
0.527 * * * *\end{array}$ \\
\hline & $(0.165)$ & $(0.170)$ & $(0.183)$ & $(0.929)$ & $(0.162)$ & $(0.179)$ & $(0.172)$ & $(0.201)$ \\
\hline trade & $\begin{array}{c}0.006 \\
(0.048)\end{array}$ & $\begin{array}{c}0.015 \\
(0.046)\end{array}$ & $\begin{array}{c}0.001 \\
(0.051)\end{array}$ & $\begin{array}{c}0.026 \\
(0.048)\end{array}$ & $\begin{array}{c}0.136 \\
(0.290)\end{array}$ & $\begin{array}{c}0.011 \\
(0.047)\end{array}$ & $\begin{array}{c}0.025 \\
(0.052)\end{array}$ & $\begin{array}{c}0.023 \\
(0.058)\end{array}$ \\
\hline$\pi$ & $\begin{array}{l}-0.076^{*} \\
(0.045)\end{array}$ & $\begin{array}{l}-0.080 \\
(0.044)\end{array}$ & $\begin{array}{l}-0.082^{*} \\
(0.049)\end{array}$ & $\begin{array}{l}-0.083^{*} \\
(0.046)\end{array}$ & $\begin{array}{l}-0.072 \\
(0.045)\end{array}$ & $\begin{array}{c}-1.052 \\
(0818)\end{array}$ & $\begin{array}{l}-0.079 * \\
(0.047)\end{array}$ & -0.124 \\
\hline inst & & $\begin{array}{l}0.076 \text { *** } \\
(0.017)\end{array}$ & $\begin{array}{l}0.076^{* * *} \\
(0.018)\end{array}$ & $\begin{array}{l}0.074 * * * \\
(0.017)\end{array}$ & $\begin{array}{l}0.076 * * * \\
(0.017)\end{array}$ & $\begin{array}{l}0.069 * * * \\
(0.018)\end{array}$ & $\begin{array}{l}-0.068 \\
(0.124)\end{array}$ & $\begin{array}{l}0.089 * * * \\
(0.023)\end{array}$ \\
\hline credit & $\begin{array}{l}-0.148 * * * \\
(0.049)\end{array}$ & $\begin{array}{l}-0.154 * * * \\
(0.050)\end{array}$ & $\begin{array}{l}-0.167 * * * \\
(0.054)\end{array}$ & $\begin{array}{l}-0.164 * * * \\
(0.048)\end{array}$ & $\begin{array}{l}-0.152 * * * \\
(0.050)\end{array}$ & $\begin{array}{l}-0.156^{* * * *} \\
(0.047)\end{array}$ & $\begin{array}{l}-0.159 * * * \\
(0.051)\end{array}$ & $\begin{array}{l}-0.931 * * \\
(0.411)\end{array}$ \\
\hline $\begin{array}{l}\log n \\
\log \left(g_{n}+g_{y}+\delta\right)\end{array}$ & $\begin{array}{c}-0.073 \\
(0.095) \\
-0.233 \\
(0.144) \\
\end{array}$ & \begin{tabular}{|c|}
-0.050 \\
$(0.097)$ \\
$-0.251^{*}$ \\
$(0.145)$ \\
\end{tabular} & \begin{tabular}{|l|l}
-0.151 \\
$(0.112)$ \\
-0.117 \\
$(0.169)$ \\
\end{tabular} & $\begin{array}{c}-0.108 \\
(0.105) \\
-0.293 * \\
(0.150) \\
\end{array}$ & \begin{tabular}{|l|l|}
-0.057 \\
$(0.102)$ \\
-0.257 \\
$(0.157)$ \\
\end{tabular} & \begin{tabular}{|c|}
-0.069 \\
$(0.093)$ \\
$-0.250^{*}$ \\
$(0.142)$ \\
\end{tabular} & \begin{tabular}{|l|l}
-0.141 \\
$(0.115)$ \\
-0.197 \\
$(0.153)$ \\
\end{tabular} & \begin{tabular}{|c|}
$-0.302 * *$ \\
$(0.144)$ \\
-0.183 \\
$(0.181)$ \\
\end{tabular} \\
\hline $\begin{array}{l}\log r e m / y \times \\
\log y_{t-1} / n_{t-1} \\
\log r e m / y \times \log h \\
\log r e m / y \times s \\
\log r e m / y \times \text { trade } \\
\log r e m / y \times \pi \\
\log r e m / y \times \text { inst } \\
\log r e m / y \times \text { credit }\end{array}$ & & \begin{tabular}{|c|}
0.001 \\
$(0.012)$
\end{tabular} & $\begin{array}{l}-0,101 \\
(0.061)\end{array}$ & \begin{tabular}{|l}
-0.205 \\
$(0.225)$
\end{tabular} & $\begin{array}{c}0.029 \\
(0.062)\end{array}$ & $\begin{array}{l}-0.228 \\
(0.191)\end{array}$ & $\begin{array}{l}-0.037 \\
(0.032)\end{array}$ & $\begin{array}{l}-0.135 * * \\
(0.069) \\
\end{array}$ \\
\hline constant & $\begin{array}{l}0.418^{* * *} \\
(0.133) \\
\end{array}$ & \begin{tabular}{|l|}
$0.450^{* * * *}$ \\
$(0.126)$
\end{tabular} & \begin{tabular}{|l|}
0.563 **** \\
$(0.161)$
\end{tabular} & \begin{tabular}{|l|}
$0.416^{\text {**** }}$ \\
$(0.134)$
\end{tabular} & \begin{tabular}{|c|}
$0.388^{* * *}$ \\
$(0.170)$ \\
\end{tabular} & $\begin{array}{l}-0.001 \\
(0.343) \\
\end{array}$ & \begin{tabular}{|l|}
0.372 *** \\
$(0.142)$ \\
\end{tabular} & $\begin{array}{l}0.472 * * * \\
(0.180) \\
\end{array}$ \\
\hline $\begin{array}{l}\text { fixed effects } \\
\text { time dummies }\end{array}$ & $\begin{array}{l}\text { yes } \\
\text { yes } \\
\end{array}$ & $\begin{array}{l}\text { yes } \\
\text { yes }\end{array}$ & $\begin{array}{l}\text { yes } \\
\text { yes }\end{array}$ & $\begin{array}{l}\text { yes } \\
\text { yes }\end{array}$ & $\begin{array}{l}\text { yes } \\
\text { yes }\end{array}$ & $\begin{array}{l}\text { yes } \\
\text { yes } \\
\end{array}$ & $\begin{array}{l}\text { yes } \\
\text { yes }\end{array}$ & $\begin{array}{l}\text { yes } \\
\text { yes }\end{array}$ \\
\hline $\begin{array}{l}\text { test of o.r. } \\
(p \text {-value })\end{array}$ & 0.0001 & 0.0001 & 0.0033 & 0.0001 & 0.0002 & 0.0003 & 0.0001 & 0.0051 \\
\hline$N$ & 407 & 407 & 407 & 402 & 406 & 406 & 407 & 384 \\
\hline
\end{tabular}

Note: Dependent variable is a 5-year cumulative growth rate of GDP per capita; standard errors are in parentheses; $*$, **, *** denotes significance level of $10 \%, 5 \%$ and $1 \%$ respectively.

Source: Authors' estimation. 
T a ble 3

Estimation Results II. - Interacting Remittances-to-GDP Ratio with Dummy Variables Denoting Larger-than-threshold Values

\begin{tabular}{|c|c|c|c|c|c|c|c|c|}
\hline & (1) & (2) & (3) & (4) & (5) & (6) & (7) & (8) \\
\hline threshold & - & median & median & 10 th per. & median & median & median & 25 th per. \\
\hline $\log r e m / y$ & $\begin{array}{l}0.063 * * \\
(0.024)\end{array}$ & $\begin{array}{l}0.046^{* * *} \\
(0.019)\end{array}$ & $\begin{array}{l}0.094 * * \\
(0.035)\end{array}$ & $\begin{array}{l}0.072 * * \\
(0.031)\end{array}$ & $\begin{array}{l}0.067 * * * \\
(0.024)\end{array}$ & $\begin{array}{l}0.065^{* *} \\
(0.024)\end{array}$ & $\begin{array}{l}0.074 * * \\
(0.025)\end{array}$ & $\begin{array}{c}0.063 * \\
(0.028)\end{array}$ \\
\hline $\log y_{t-1} / n_{t-1}$ & $\begin{array}{l}0.234 * * * \\
(0.052)\end{array}$ & $\begin{array}{l}-0.228 \text { *** } \\
(0.051)\end{array}$ & $\begin{array}{l}0.236 \text { *** } \\
(0.053)\end{array}$ & $\begin{array}{l}-0.206 \text { *** } \\
(0.050)\end{array}$ & $\begin{array}{l}0.231 \text { *** } \\
(0.052)\end{array}$ & $\begin{array}{l}-0.233 \text { *** } \\
(0.052)\end{array}$ & $\begin{array}{l}-0.239 \text { *** } \\
(0.053)\end{array}$ & $\begin{array}{l}-0.206 * * * \\
(0.056)\end{array}$ \\
\hline $\log h$ & $\begin{array}{c}0.096 \\
(0.186)\end{array}$ & $\begin{array}{c}0.079 \\
(0.180)\end{array}$ & $\begin{array}{c}-0.081 \\
(0.201)\end{array}$ & \begin{tabular}{|c|}
0.102 \\
$(0.81)$
\end{tabular} & $\begin{array}{c}0.113 \\
(0.189)\end{array}$ & $\begin{array}{c}0.094 \\
(0.187)\end{array}$ & $\begin{array}{c}0.095 \\
(0.194)\end{array}$ & $\begin{array}{c}0.021 \\
(0.193)\end{array}$ \\
\hline$s$ & $\begin{array}{l}0.640^{* * * *} \\
(0.165)\end{array}$ & $\begin{array}{l}0.663 \text { *** } \\
(0.158)\end{array}$ & $\begin{array}{l}0.576 \text { *** } \\
(0.176)\end{array}$ & $\begin{array}{l}0.558 * * * \\
(0.182)\end{array}$ & $\begin{array}{l}0.630 * * * \\
(0.167)\end{array}$ & $\begin{array}{l}0.644 * * * \\
(0.166)\end{array}$ & $\begin{array}{l}0.626 \text { *** } \\
(0.170)\end{array}$ & $\begin{array}{l}0.604 * * * \\
(0.173)\end{array}$ \\
\hline trade & $\begin{array}{c}0.006 \\
(0.048)\end{array}$ & $\begin{array}{c}0.017 \\
(0.045)\end{array}$ & $\begin{array}{l}-0.006 \\
(0.051)\end{array}$ & $\begin{array}{l}0.044 \\
(0.045)\end{array}$ & $\begin{array}{c}-0.046 \\
(0.076)\end{array}$ & $\begin{array}{c}0.008 \\
(0.048)\end{array}$ & $\begin{array}{c}-0.002 \\
(0.049)\end{array}$ & $\begin{array}{c}0.027 \\
(0.050)\end{array}$ \\
\hline$\pi$ & $\begin{array}{c}-0.076^{*} \\
(0.045)\end{array}$ & $\begin{array}{c}-0.080^{*} \\
(0.044)\end{array}$ & $\begin{array}{c}-0.086^{*} \\
(0.047)\end{array}$ & $\begin{array}{l}-0.085^{* *} \\
(0.045)\end{array}$ & $\begin{array}{c}-0.077 * \\
(0.046)\end{array}$ & $\begin{array}{c}-0.089 \\
(0.348)\end{array}$ & $\begin{array}{c}-0.073 \\
(0.047)\end{array}$ & $\begin{array}{r}-0.187 * \\
(0.107)\end{array}$ \\
\hline inst & $\begin{array}{l}0.076^{* * * *} \\
(0.017)\end{array}$ & $\begin{array}{l}0.075^{* * * *} \\
(0.016)\end{array}$ & $\begin{array}{l}0.075 * * * \\
(0.017)\end{array}$ & $\begin{array}{l}0.065^{* * * *} \\
(0.016)\end{array}$ & $\begin{array}{l}0.079 * * * * \\
(0.017)\end{array}$ & $\begin{array}{l}0.078 * * * \\
(0.017)\end{array}$ & $\begin{array}{l}0.075^{* * * *} \\
(0.020)\end{array}$ & $\begin{array}{l}0.073 * * * \\
(0.018)\end{array}$ \\
\hline credit & $\begin{array}{c}-0.148 * * * \\
(0.0489) \\
\end{array}$ & $\begin{array}{l}-0.160 * * * \\
(0.046)\end{array}$ & $\begin{array}{l}-0.153 * * * \\
(0.049) \\
\end{array}$ & $\begin{array}{l}-0.156^{* * * *} \\
(0.048)\end{array}$ & \begin{tabular}{|}
$-0.145 * * *$ \\
$(0.049)$ \\
\end{tabular} & $\begin{array}{l}-0.150 * * * \\
(0.049)\end{array}$ & $\begin{array}{l}-0.137 * * * \\
(0.050) \\
\end{array}$ & $\begin{array}{c}-0.616 \\
(0.412) \\
\end{array}$ \\
\hline $\begin{array}{l}\log n \\
\log \left(g_{n}+g_{y}+\delta\right)\end{array}$ & \begin{tabular}{|l|}
-0.073 \\
$(0.095)$ \\
-0.233 \\
$(0.144)$ \\
\end{tabular} & \begin{tabular}{|c|}
-0.065 \\
$(0.092)$ \\
$-0.256^{*}$ \\
$(0.138)$ \\
\end{tabular} & \begin{tabular}{|l}
-0.126 \\
$(0.103)$ \\
-0.184 \\
$(0.154)$ \\
\end{tabular} & \begin{tabular}{|l}
-0.88 \\
$(0.094)$ \\
-0.299 \\
$(0.137)$ \\
\end{tabular} & $\begin{array}{c}-0.077 \\
(0.096) \\
-0.222 \\
(0.146) \\
\end{array}$ & \begin{tabular}{|c|}
-0.071 \\
$(0.096)$ \\
-0.217 \\
$(0.146)$ \\
\end{tabular} & \begin{tabular}{|c|}
-0.082 \\
$(0.098)$ \\
-0.222 \\
$(0.150)$ \\
\end{tabular} & \begin{tabular}{|l|}
-0.103 \\
$(0.104)$ \\
-0.203 \\
$(0.158)$ \\
\end{tabular} \\
\hline 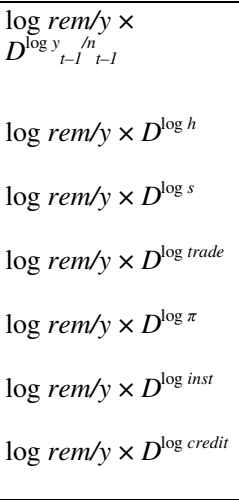 & & $\begin{array}{l}-0.001 \\
(0.004)\end{array}$ & $\begin{array}{l}-0.045^{* *} \\
(0.029)\end{array}$ & $\begin{array}{l}-0.036^{* *} \\
(0.015)\end{array}$ & $\begin{array}{c}0.037 \\
(0.040)\end{array}$ & $\begin{array}{c}0.014 \\
(0.334)\end{array}$ & $\begin{array}{c}0.018 \\
(0.050)\end{array}$ & $\begin{array}{l}-0.741^{*} \\
(-0.403)\end{array}$ \\
\hline constant & $\begin{array}{l}2.826 \\
(-1.819)\end{array}$ & $\begin{array}{r}2.4527 \\
(1.742) \\
\end{array}$ & $\begin{array}{l}4.010 * * \\
(2.031)\end{array}$ & $\begin{array}{c}2.574 \\
(1.726)\end{array}$ & $\begin{array}{c}2.920 \\
(1.838)\end{array}$ & $\begin{array}{c}2.845 \\
(1.828)\end{array}$ & $\begin{array}{c}3.090 \\
(1.869) \\
\end{array}$ & $\begin{array}{c}3.176^{*} \\
(1.995)\end{array}$ \\
\hline $\begin{array}{l}\text { fixed effects } \\
\text { time dummies }\end{array}$ & $\begin{array}{l}\text { yes } \\
\text { yes }\end{array}$ & $\begin{array}{l}\text { yes } \\
\text { yes }\end{array}$ & $\begin{array}{l}\text { yes } \\
\text { yes }\end{array}$ & $\begin{array}{l}\text { yes } \\
\text { yes }\end{array}$ & $\begin{array}{l}\text { yes } \\
\text { yes }\end{array}$ & $\begin{array}{l}\text { yes } \\
\text { yes }\end{array}$ & $\begin{array}{l}\text { yes } \\
\text { yes }\end{array}$ & $\begin{array}{l}\text { yes } \\
\text { yes }\end{array}$ \\
\hline test of o.r. ( $p$-value) & 0.0001 & 0.0004 & 0.0001 & 0.0002 & 0.0002 & 0.0006 & 0.0001 & 0.0001 \\
\hline$N$ & 407 & 407 & 407 & 402 & 406 & 406 & 407 & 384 \\
\hline
\end{tabular}

Note: Dependent variable is a 5-year cumulative growth rate of GDP per capita; standard errors are in parentheses; *, **, *** denotes significance level of $10 \%, 5 \%$ and $1 \%$ respectively.

Source: Authors' estimation.

In the first column of Table 2 we report simple IV-estimate without interaction terms. We find a significant positive effect of remittances on economic growth even without making impact of remittances on growth conditional on other determinants. The effect is substantial, increasing remittances by $10 \%$ is 
associated with additional $0.12 \mathrm{pp}$. of growth rate $(\log 1.1 \times 0.063 / 5=0.0012) .{ }^{11}$ To provide an idea how remittances contribute to economic growth, we perform few back-of-the-envelope calculations. We focus on countries in the lowest quartile of income distribution during the period $2013-2017$.

On average, in this group of countries remittances amounted to $3.7 \%$ of GDP, growth rate of GDP per capita being $1.7 \%$. Instead, suppose that remittances were equal to $1.7 \%$, what is the median value in the whole sample of countries. Based on model 1 from Table 2, economic growth would decrease from 1.7\% to $0.8 \%$. In other words, contribution of remittances to GDP growth is approximately $0.9 \mathrm{pp}$. To put this number into perspective, we performed analogical calculations for other covariates. We find out that low quality of institutions decreases economic growth in this group of countries by $1.1 \mathrm{pp}$. and low value of human capital by $0.9 \mathrm{pp}$.

In models $2-8$, link between remittances-to-GDP ratio and economic growth depends on other covariates. We find it noteworthy that the effect of remittances on growth does not depend on level of economic development (coefficients corresponding to $\log \mathrm{rem} / y \times \log y_{t-1} / n_{t-1}$ and $\log \mathrm{rem} / y \times D^{x \log y_{t-1} / n_{t-1}}$ are both not statistically significant). This does not mean that the effect of remittances on growth is same in poor and rich countries, but it is likely not level of development per se what determines the impact of remittances, but other fundamentals.

Results in both Table 2 and 3 suggest that in countries with low levels human capital remittances have a stronger effect on economic growth ( $p$-value of coefficient corresponding to $\log r e m / y \times \log h$ is 0.101 ). Moving from a country in a lower half of distribution of human capital to a country in an upper half reduces the impact of remittances by half $(0.094-0.045=0.049$ based on Table 3$)$. A tentative hypothesis is that in such countries brain drain which is a natural accompanying effect of high remittances is less costly (note also that highly educated migrants tend to send fewer money back home, Niimi, Ozden and Schiff, 2008).

We also find evidence that the effect of remittances increases in countries with lower savings rate and lower financial development. Standard cross-country deviation of credit is approximately 0.5 , increasing credit by one standard deviation

11 This is in line with Giuliano and Ruiz-Arranz (2009). Using estimates from Table 1 and descriptive statistics from Table A1 of paper by Giuliano and Ruiz-Arranz we find out that on average, increasing remittance by $10 \%$ also increases growth of GDP by $0.12 \mathrm{pp}$. Our results are not directly comparable to Catrinescu et al. (2009), since these authors do not perform standard growth regressions. However, long-run elasticities of GDP growth on remittances are of similar magnitudes than long-run elasticities implied by our estimates. Note that long-run effect of remittances on GDP in model 1 in Table 2 is given by $0.063 / 0.234=0.278$. Catrinescu et al. report values ranging from 0.00 to 0.42 . 
therefore almost erases a positive effect of remittances on growth $(0.068+0.5 \times$ $-0.135=0.0005$ based on estimates in Table 2). Negative relationship between credit-to-GDP ratio and the effect of remittances has already been documented by Giuliano and Ruiz-Arranz (2009). These authors suggest that in countries with under-developed financial markets remittances tend to serve as a substitute for services usually provided by financial institutions. Our finding that the effect of remittances is also stronger in countries with low savings rate suggests that remittances can promote growth even when savings are discouraged by factors other than low financial development.

Note that interaction terms with human capital and with savings rate are significant in discrete setting in Table 3, but not in continuous setting in Table 2. This indicates that although there are significant differences between groups of countries (below and above the threshold), a link between the effect of remittances on growth and conditioning variables within groups is weaker. Therefore, our preferred specifications are those based on thresholds.

In addition to the effect of remittances on growth, other results can be obtained by inspecting Tables 2 and 3, each rather typical of growth regressions. We detect presence of conditional convergence in our sample, a positive effect of savings rate and human capital (even though the effect of human capital on economic growth is not significant, this is not uncommon in growth regression, see for example discussion in Barro, 2015). We also document a negative effect of inflation and a positive effect of quality of institutions. Note also a negative effect of credit-to-GDP ratio on growth which is supportive of hypothesis of 'too much finance ${ }^{e}$ (Arcand, Berkes and Panizza, 2015). ${ }^{12}$

\section{Concluding Remarks}

Even though remittances are a single most important monetary flow in many developing countries and their importance is increasing, results of the estimation of the effects of remittances on growth are ambiguous. The reason for this is endogenous nature of remittances. In this paper, we provided a detailed discussion of endogeneity and estimated remittances-growth relationship using three types of instruments - internal, microeconomically motivated and geographical instruments. We documented a positive effect of remittances on economic growth but found that this relationship is dependent on other growth determinants. In particular, remittances tend to exert stronger impact on growth in countries with

\footnotetext{
${ }^{12}$ Since our intention is not to identify optimal size of financial sector, we do not include square of credit-to-GDP ratio in baseline estimation. However, including this term does not lead to change in results. Due to space constraint we do not report estimation with square of credit.
} 
low level of financial development, low savings rate and low level of human capital. This indicates that remittances tend to substitute for services usually provided by financial sector, but also promote growth when savings (and investment) are subdued for other reasons. It is not low level of economic development per se what makes remittances an effective source of growth but abovementioned determinants. In countries with high level of human capital the effect of remittances on growth is weaker most likely due to brain drain associated with migration. This has straightforward policy implications. Undeveloped countries can benefit from elimination of restrictions on outward remittances, faster adoption of digital financial services (which make it easier to receive remittances from more developed economies) and increased migration in general. Once human capital is high enough and financial markets are developed, remittances cease to function as engine of growth. They are no longer needed as source of liquidity (since that will be provided by financial market) and brain drain associated with migration negatively impact growth potential. Therefore, remittances are only a temporary source of growth.

\section{References}

ADAMS, R. H. Jr. (1991): The Economic Uses and Impact of International Remittances in Rural Egypt. Economic Development and Cultural Change, 39, No. 4, pp. 695 - 722.

ADAMS, R. H. Jr. - PAGE, J. (2005): Do International Migration and Remittances Reduce Poverty in Developing Countries? World Development, 33, No. 10, pp. 1645 - 1669.

ARCAND, J. - BERKES, L. E. - PANIZZA, U. (2015): Too Much Finance? Journal of Economic Growth, 20, No. 2, pp. $105-148$.

ARELLANO, M. - BOND, S. (1991): Some Tests of Specification for Panel Data: Monte Carlo Evidence and an Application to Employment Equations. Review of Economic Studies, 58, No. 2, pp. $277-297$.

AZIZI, S. (2018): Why Do Migrants Remit? The World Economy. 41, No. 7, pp. 429 - 452.

BARRO, R. J. (2015): Convergence and Modernisation. Economic Journal, 125, No. 585, pp. 911 -942 .

BARRO, R. J. - LEE, J.-W. (1994): Sources of Economic Growth. Carnegie-Rochester Conference Series on Public Policy, 40, No. 1, pp. $1-46$.

BILlMEIER, A. - MASSA, I. (2009): What Drives Stock Market Development in Emerging Markets - Institutions, Remittances, or Natural Resources? Emerging Markets Review, 10, No. 1 , pp. $23-35$.

BLUNDELL, R. - BOND, S. (1998): Initial Conditions and Moment Restrictions in Dynamic Panel Data Models. Journal of Econometrics, 87, No. 1, pp. 115 - 143.

CANER, M. - HANSEN, B. (2004): Instrumental Variable Estimation of a Threshold Model. Econometric Theory, 20, No. 5, pp. $813-843$.

CATRINESCU, N. - LEON-LEDESMA, M. - PIRACHA, M. - QUILLIN, B. (2009): Remittances, Institutions and Economic Growth. World Development, 37, No. 1, pp. 81 - 92.

CHAMI, R. - FULLENKAMP, C - JAHJAH, S. (2005): Are Immigrant Remittance Flows a Source of Capital for Development? IMF Staff Papers, 52, No. 1, pp. 55 - 81. 
DRIFFIELD, N. - JONES, C. (2013): Impact of FDI, ODA and Migrant Remittances on Economic Growth in Developing Countries: A Systems Approach. The European Journal of Development Research, 25, No. 2, pp. 173 - 196.

DURAND, J. - KANDEL, W. - PARRADO, E. A. - MASSEY, D. S. (1996): International Migration and Development in Mexican Communities. Demography, 33, No. 2, pp. 249 - 264.

EUROSTAT (2019): Personal Remittances Statistics. Statistics Explained. Luxembourg: Eurostat.

FAINI, R. (2007): Migration and Remittances: Impact on the Countries of Origin. Revue d'Economie du Developpement, 15 , No. 2, pp. $153-182$.

FREUND, C. - SPATAFORA, N. (2005): Remittances: Transaction Costs, Determinants, and Informal Flows. [Policy Research Working Paper Series 3704.] Washington, DC: The World Bank.

GAMMELTOFT, P. (2002): Remittances and Other Financial Flows to Developing Countries. Technical Report, 40, No. 5, pp. $181-211$.

GAPEN, M. T. - CHAMI, R. - MONTIEL, P. J. - BARAJAS, A. - FULLENKAMP, C. (2009): Do Workers' Remittances Promote Economic Growth? [IMF Working Papers 09/153.] Washington, DC: International Monetary Fund.

GIULIANO, P. - RUIZ-ARRANZ, M. (2009): Remittances, Financial Development, and Growth. Journal of Development Economics, 90, No. 1, pp. 144 - 152.

GLYTSOS, N. P. (1993): Measuring the Income Effects of Migrant Remittances: A Methodological Approach Applied to Greece. Economic Development and Cultural Change, 42, No. 1, pp. $131-168$.

HANSEN, B. E. (1997): Threshold Effects in Non-dynamic Panels: Estimation, Testing and Inference. [Boston College Working Papers in Economics 365.] Boston: Boston College Department of Economics.

HANSON, G. H. - WOODRUFF, C. (2003): Emigration and Educational Attainment in Mexico. Cambridge: NBER.

IMF (2005): Two Current Issues Facing Developing Countries. In: World Economic Outlook. Washington, DC: International Monetary Fund.

IMF (2009): Balance of Payments and International Investment Position Manual. Washington, DC: International Monetary Fund.

IMF (2020): IMF Balance of Payments Database. Washington, DC: International Monetary Fund. Available at: $\langle$ https://data.imf.org/regular.aspx?key=62805743>.

KIIO, J. - SOI, N. - BUIGUT, K. (2014). The Impact of Worker's Remittances On Economic Growth: Evidence from Keyna. Journal of Economics and Sustainable Development, 5, No. 26, pp. $83-96$.

MANKIW, N. G. - ROMER, D. - WEIL, D. (1992): A Contribution to the Empirics of Economic Growth. The Quarterly Journal of Economics, 107, No. 2, pp. 407 - 437.

MUNZELE, M. - RATHA, D. (2005): Remittances: Development Impact and Future Prospects. Washington, DC: The World Bank.

NIIMI, Y. - OZDEN, C. - SCHIFF, M. (2008): Remittances and the Brain Drain: Skilled Migrants Do Remit Less. [IZA Discussion Papers 3393.] Bonn: Institute of Labor Economics (IZA).

PAGE, J. - PLAZA, S. (2006): Migration Remittances and Development: A Review of Global Evidence. Journal of African Economies, 15, No. IS2, pp. 245 - 336.

RATHA, D. (2003): Worker's Remittances: An Important and Stable Source of External Development Finance. Washington, DC: The World Bank.

RATHA, D. (2006): Leveraging Remittances for Development. [Proceedings of the 2006 Conference on Migration, Trade and Development.] Dallas: Federal Reserve Bank of Dallas.

RATHA, D. (2013): The Impact of Remittances on Economic Growth and Poverty Reduction. Washington, DC: Migration Policy Institute.

RODRIK, D. - SUBRAMANIAN, A. - TREBBI, F. (2004): Institutions Rule: The Primacy of Institutions over Geography and Integration in Economic Development. Journal of Economic Growth, 9, No. 2, pp. $131-165$. 
ROMER, D. H. - FRANKEL, J. A. (1999). Does Trade Cause Growth? American Economic Review, 89, No. 3, pp. $379-399$.

SEO, M. H. - SHIN, Y. (2016): Dynamic Panels with Threshold Effect and Endogeneity. Journal of Econometrics, 195, No. 2, pp. $169-186$.

SIDDIQUE, A. - SELVANATHAN, E. A. - SELVANATHAN, S. (2011): Remittances and Economic Growth: Empirical Evidence from Bangladesh, India and Sri Lanka. Journal of Development Studies, 48, No. 8, pp. 1045 - 1062.

SOLOW, R. M. (1956): A Contribution to the Theory of Economic Growth. The Quarterly Journal of Economics, 70, No. 1, pp. $65-94$.

WB (2006): The Development Impact of Workers' Remittances in Latin America. Vol. 2. Washington, DC: The World Bank.

WB (2018): Migration and Remittances: Recent Developments and Outlook. Washington, DC: The World Bank.

WB (2019): Migration and Remittances: Recent Developments and Outlook. Washington, DC: The World Bank.

WOOLDRIGE, J. M. (2001): Econometric Analysis of Cross Section and Panel Data. Volume 1 of MIT Press Books. Cambridge/London: The MIT Press.

\section{A n n ex}

T a ble A1

Remittances and Economic Development

\begin{tabular}{|c|c|c|c|c|}
\hline & (1) & (2) & (3) & (4) \\
\hline Dependant variable & $\log \mathrm{rem} / \mathrm{y}$ & $\log \mathrm{rem} / \mathrm{y}$ & $d \log \mathrm{rem} / \mathrm{y}$ & $d \log r e m / y$ \\
\hline $\begin{array}{l}\text { Data structure } \\
\text { Frequency } \\
\text { Period covered }\end{array}$ & $\begin{array}{c}\text { cross section } \\
- \\
2017\end{array}$ & $\begin{array}{c}\text { unbalanced panel } \\
\text { annual } \\
1971-2017\end{array}$ & $\begin{array}{c}\text { cross section } \\
- \\
2017\end{array}$ & $\begin{array}{c}\text { unbalanced panel } \\
\text { annual } \\
1971-2017\end{array}$ \\
\hline $\begin{array}{l}\text { Constant } \\
\log y / p o p \\
\Delta \log y / p o p\end{array}$ & $\begin{array}{l}2.788^{* *} \\
(-1.103) \\
-0.755^{* * *} \\
(-0.115)\end{array}$ & $\begin{array}{l}2.130 \\
(-2.256) \\
-0.910 * * * \\
(-0.288)\end{array}$ & $\begin{array}{c}0.087^{*} \\
(-0.049) \\
\\
-1.171 \\
(-1.120)\end{array}$ & $\begin{array}{l}-0.822 * * * \\
(-0.126)\end{array}$ \\
\hline $\begin{array}{l}\text { Fixed effects } \\
\text { Time dummies }\end{array}$ & $\begin{array}{l}- \\
-\end{array}$ & $\begin{array}{l}\text { yes } \\
\text { yes }\end{array}$ & $\begin{array}{l}- \\
-\end{array}$ & $\begin{array}{l}\text { yes } \\
\text { yes }\end{array}$ \\
\hline $\begin{array}{l}N \\
R^{2}\end{array}$ & $\begin{array}{l}169 \\
0.21\end{array}$ & $\begin{array}{c}5,558 \\
0.12 \\
\end{array}$ & $\begin{array}{l}168 \\
0.01\end{array}$ & $\begin{array}{c}5,357 \\
0.02\end{array}$ \\
\hline
\end{tabular}

Note: Standard errors are in parentheses; * **, *** denotes significance level of $10 \%, 5 \%$ and $1 \%$ respectively. In regression (1), $y$ is in purchasing power parity in current prices. In regressions (2) - (4) constant prices in 2010 USD are used.

Source: Authors' estimation. 
Table A2

Remittances and Country Size

\begin{tabular}{|c|c|c|c|c|c|c|}
\hline & (1) & (2) & (3) & (4) & (5) & (6) \\
\hline Dependant variable & $\log \mathrm{rem} / \mathrm{y}$ & $\log \mathrm{rem} / \mathrm{y}$ & $\log \mathrm{rem} / \mathrm{y}$ & $\log \mathrm{rem} / \mathrm{y}$ & $\log \mathrm{rem} / \mathrm{y}$ & $\log \mathrm{rem} / \mathrm{y}$ \\
\hline $\begin{array}{l}\text { Data structure } \\
\text { Frequency } \\
\text { Period covered }\end{array}$ & $\begin{array}{c}\text { cross } \\
\text { section } \\
- \\
2017\end{array}$ & $\begin{array}{c}\text { cross } \\
\text { section } \\
- \\
2017\end{array}$ & $\begin{array}{c}\text { cross } \\
\text { section } \\
- \\
2017 \\
\end{array}$ & $\begin{array}{c}\text { unbalanced } \\
\text { panel } \\
\text { annual } \\
1971-2017\end{array}$ & $\begin{array}{c}\text { unbalanced } \\
\text { panel } \\
\text { annual } \\
1971-2017\end{array}$ & $\begin{array}{c}\text { unbalanced } \\
\text { panel } \\
\text { annual } \\
1971-2017\end{array}$ \\
\hline $\begin{array}{l}\text { Constant } \\
\log \text { pop } \\
\text { log area }\end{array}$ & $\begin{array}{l}-1.36 \\
(-0.947) \\
-0.183 * * * \\
(-0.06)\end{array}$ & $\begin{array}{l}-2.043 * * * \\
(-0.727) \\
-0.194 * * * \\
(-0.062)\end{array}$ & $\begin{array}{c}-2.584 * * \\
(-1.027) \\
0.068 \\
(-0.143) \\
-0.241 * \\
(-0.139) \\
\end{array}$ & $\begin{array}{l}-1.556 * * * \\
(-0.489) \\
-0.246^{* * *} \\
(-0.011)\end{array}$ & $\begin{array}{l}-2.287 * * * \\
(-0.483) \\
\\
-0.257 * * * \\
(-0.01)\end{array}$ & $\begin{array}{l}-2.619 * * * \\
(-0.505) \\
0.044 * * \\
(-0.022) \\
-0.287 * * * \\
(-0.02)\end{array}$ \\
\hline $\begin{array}{l}\text { Fixed effects } \\
\text { Time dummies }\end{array}$ & $\begin{array}{l}- \\
- \\
\end{array}$ & - & $\begin{array}{l}- \\
- \\
\end{array}$ & $\begin{array}{l}\text { no } \\
\text { yes }\end{array}$ & $\begin{array}{c}\text { no } \\
\text { yes } \\
\end{array}$ & $\begin{array}{c}\text { no } \\
\text { yes } \\
\end{array}$ \\
\hline $\begin{array}{l}N \\
R^{2}\end{array}$ & $\begin{array}{c}170 \\
0.04\end{array}$ & $\begin{array}{l}170 \\
0.07\end{array}$ & $\begin{array}{l}170 \\
0.07\end{array}$ & $\begin{array}{c}5,693 \\
0.1\end{array}$ & $\begin{array}{c}5,660 \\
0.14\end{array}$ & $\begin{array}{c}5,660 \\
0.14\end{array}$ \\
\hline
\end{tabular}

Note: Standard errors are in parentheses; $*, * *, * * *$ denotes signi_cance level of $10 \%, 5 \%$ and $1 \%$ respectively. Source: Authors' estimation.

Table A3

Remittances and Economic Dynamism

\begin{tabular}{|l|c|c|c|c|}
\hline & $(1)$ & $(2)$ & $(3)$ & $(4)$ \\
\hline Dependant variable & $\log \mathrm{rem} / \mathrm{y}$ & $\log \mathrm{rem} / \mathrm{y}$ & $\log \mathrm{rem} / \mathrm{y}$ & $\log \mathrm{rem} / \mathrm{y}$ \\
\hline Data structure & cross section & unbalanced panel & cross section & unbalanced panel \\
Frequency & - & annual & - & $1971-2017$ \\
Period covered & 2017 & $1971-2017$ & 2017 & 2.284 \\
\hline Constant & $-4.442 * * *$ & $-5.081 * * *$ & 0.934 & $(-2.243)$ \\
& $(-0.209)$ & $(-0.351)$ & $(-0.786)$ & $2.075 * * *$ \\
$d \log y /$ pop & 9.445 & $2.829 * * *$ & 7.231 & $(-0.514)$ \\
& $(-6.237)$ & $(-0.545)$ & $(-5.604)$ & $-0.947 * * *$ \\
$\log y_{t-1} /$ pop & & & $-0.620 * * *$ & $(-0.287)$ \\
\hline Fixed effects & & & $(-0.084)$ & yes \\
Time dummies & - & yes & - & yes \\
\hline$N$ & - & 5,533 & 169 & 5,533 \\
$R^{2}$ & 169 & 0.1 & 0.23 & 0.13 \\
\hline
\end{tabular}

Note: Standard errors are in parentheses; *, **, *** denotes significance level of $10 \%, 5 \%$ and $1 \%$ respectively. Source: Authors' estimation. 
Table A4

First-stage Regressions for Results in Table 2

\begin{tabular}{|c|c|c|c|c|c|c|c|c|}
\hline & (1) & (2) & (3) & (4) & (5) & (6) & (7) & (8) \\
\hline$z$ & - & $\log y_{t-1} / n_{t-1}$ & $\log h$ & $s$ & trade & $\pi$ & inst & credit \\
\hline \multicolumn{9}{|c|}{ Part I.: First stage regression for log of remittances-to-GDP ratio } \\
\hline $\log y_{t-I} / n_{t-I}$ & 0.290 & -0.040 & 0.207 & 0.221 & 0.251 & 0.209 & 0.317 & 0.151 \\
\hline & $(0.320)$ & $(0.496)$ & $(0.327)$ & $(0.324)$ & $(0.317)$ & $(0.324)$ & $(0.329)$ & $(0.343)$ \\
\hline $\log h$ & $\begin{array}{c}-0.936 \\
(1.126)\end{array}$ & $\begin{array}{c}-1.141 \\
(1.118)\end{array}$ & $\begin{array}{l}5.163 \\
(3.535)\end{array}$ & $\begin{array}{l}-1.426 \\
(1125)\end{array}$ & -1.224 & $\begin{array}{c}-1.009 \\
(1.137)\end{array}$ & -0.844 & -1.468 \\
\hline$s$ & $\begin{array}{l}(1.126) \\
0.933\end{array}$ & $\begin{array}{c}(1.118) \\
0.369\end{array}$ & $\begin{array}{l}(3.535) \\
1.056\end{array}$ & $\begin{array}{l}(1.125) \\
4.491\end{array}$ & 0.728 & 0.836 & $\begin{array}{l}(1.103) \\
0.952\end{array}$ & 0.674 \\
\hline & $(0.956)$ & $(0.950)$ & $(0.962)$ & $(6.769)$ & $(0.970)$ & $(0.956)$ & $(0.967)$ & $(1.019)$ \\
\hline trade & $0.664 * *$ & $0.492 *$ & $0.623 * *$ & $0.623 * *$ & 1.830 & $0.641 * *$ & $0.658 * *$ & $0.622 * *$ \\
\hline & $(0.264)$ & $(0.267)$ & $(0.271)$ & $(0.261)$ & $(2.145)$ & $(0.266)$ & $(0.269)$ & $(0.284)$ \\
\hline$\pi$ & $\begin{array}{c}-0.173 \\
(0.266)\end{array}$ & $\begin{array}{c}-0.062 \\
(0.260)\end{array}$ & $\begin{array}{c}-0.145 \\
(0.267)\end{array}$ & $\begin{array}{c}-0.016 \\
(0.265)\end{array}$ & $\begin{array}{c}0.000 \\
(0.265)\end{array}$ & $\begin{array}{c}-7.107^{*} \\
(3.890)\end{array}$ & $\begin{array}{c}-0.192 \\
(0.269)\end{array}$ & $\begin{array}{c}0.045 \\
(0.637)\end{array}$ \\
\hline inst & -0.160 & $-0.179 *$ & -0.161 & -0.151 & -0.157 & -0.151 & 0.156 & $-0.210^{* *}$ \\
\hline & $(0.100)$ & $(0.099)$ & $(0.101)$ & $(0.098)$ & $(0.100)$ & $(0.100)$ & $(0.712)$ & $(0.105)$ \\
\hline credit & $-0.486 *$ & -0.443 & $-0.523 *$ & $\begin{array}{l}-0.392 \\
(0.276)\end{array}$ & $-0.452 *$ & $-0.487 *$ & $-0.495^{*}$ & 0.426 \\
\hline $\log n$ & $\begin{array}{r}(0.276) \\
0.948 *\end{array}$ & (0.270) & $(0.278)$ & $(0.276)$ & $(0.272)$ & $\begin{array}{l}(0.278) \\
1.065 *\end{array}$ & $(0.281)$ & $\begin{array}{c}(1.757) \\
0750\end{array}$ \\
\hline $\log n$ & $\begin{array}{c}0.948^{*} \\
(0.562)\end{array}$ & $\begin{array}{c}-0.828 \\
(0.726)\end{array}$ & $\begin{array}{c}0.712 \\
(0.780)\end{array}$ & $\begin{array}{r}0.946^{*} \\
(0.567)\end{array}$ & $\begin{array}{c}0.928 * \\
(0.557)\end{array}$ & $\begin{array}{l}1.065^{*} \\
(0.580)\end{array}$ & $\begin{array}{l}1.053^{*} \\
(0.616)\end{array}$ & $\begin{array}{c}0.759 \\
(0.644)\end{array}$ \\
\hline $\log \left(g_{n}+g_{y}+\delta\right)$ & $\begin{array}{c}-2.045^{* *} \\
(0.829)\end{array}$ & $\begin{array}{c}-1.173 \\
(0.860)\end{array}$ & $\begin{array}{c}-1.883^{* *} \\
(0.880)\end{array}$ & $\begin{array}{c}-1.932 * * \\
(0.815)\end{array}$ & $\begin{array}{l}-2.160 * * * \\
(0.823)\end{array}$ & $\begin{array}{l}-2.261^{* * * *} \\
(0.835)\end{array}$ & $\begin{array}{c}-2.061 * * \\
(0.843)\end{array}$ & $\begin{array}{c}-2.524 * * * \\
(0.869)\end{array}$ \\
\hline $\log \mathrm{rem}_{t-1} / y_{t-1}$ & $0.241^{* * *}$ & $0.600^{* *}$ & $0.239^{* * *}$ & $0.260^{* * *}$ & $0.274 * * *$ & $0.234 * * *$ & $0.240^{* * *}$ & 0.207 *** \\
\hline & $(0.035)$ & $(0.239)$ & $(0.039)$ & $(0.037)$ & $(0.036)$ & $(0.036)$ & $(0.036)$ & $(0.038)$ \\
\hline $\log (\mathrm{rem} / \mathrm{y})^{G E O}$ & -0.533 & $-1.616^{*}$ & -0.541 & -0.314 & -0.012 & -0.708 & -0.448 & -0.563 \\
\hline & $(0.718)$ & $(0.930)$ & $(0.752)$ & $(0.713)$ & $(0.760)$ & $(0.733)$ & $(0.757)$ & $(0.755)$ \\
\hline $\log (r e m / y)^{R W}$ & $\begin{array}{c}-0.682 \\
(4.071)\end{array}$ & $\begin{array}{c}1.584 \\
(4.103)\end{array}$ & $\begin{array}{c}-0.868 \\
(4.097)\end{array}$ & $\begin{array}{c}2.079 \\
(4.098)\end{array}$ & $\begin{array}{c}-0.083 \\
(4.040)\end{array}$ & $\begin{array}{c}-0.851 \\
(4.146)\end{array}$ & $\begin{array}{c}-0.394 \\
(4.115)\end{array}$ & $\begin{array}{c}0.143 \\
(4.262)\end{array}$ \\
\hline$z \times \log r e m_{t-1} / y_{t-1}$ & & $-0.046^{*}$ & -0.029 & 0.109 & $0.203 * * *$ & 0.006 & 0.010 & 0.007 \\
\hline & & $(0.028)$ & $(0.111)$ & $(0.182)$ & $(0.058)$ & $(0.004)$ & $(0.022)$ & $(0.045)$ \\
\hline $\mathrm{z} \times \log (\mathrm{rem} / \mathrm{y})^{G E O}$ & & 0.055 & $0.931^{*}$ & 0.953 & 0.078 & $-1.035^{*}$ & 0.042 & 0.144 \\
\hline & & $(0.069)$ & $(0.521)$ & $(1.049)$ & $(0.351)$ & $(0.536)$ & $(0.114)$ & $(0.273)$ \\
\hline$z \times \log (\mathrm{rem} / \mathrm{y})^{R W}$ & & $\begin{array}{l}-0.531 * * * \\
(0.169)\end{array}$ & $\begin{array}{c}1.424 \\
(0.871)\end{array}$ & $\begin{array}{c}-1.994 \\
(2.908)\end{array}$ & $\begin{array}{c}0.670 \\
(0.601)\end{array}$ & $\begin{array}{c}-2.295 \\
(2.335)\end{array}$ & 0.117 & $\begin{array}{c}-0.140 \\
(0.566)\end{array}$ \\
\hline$F$-stat & 8.00 & 8.22 & 6.87 & 7.35 & 7.65 & 7.03 & 6.63 & 5.85 \\
\hline \multicolumn{9}{|c|}{ Part II.: First stage regression for interaction term } \\
\hline $\log y_{t-1} / n_{t-1}$ & & -0.361 & 0.053 & -0.015 & -0.130 & -0.068 & -0.323 & $0.400 * *$ \\
\hline & & $(4.135)$ & $(0.109)$ & $(0.036)$ & $(0.155)$ & $(0.118)$ & $(0.401)$ & $(0.170)$ \\
\hline $\log h$ & & -9.315 & 0.627 & -0.132 & 0.405 & 0.344 & $-2.500^{*}$ & 0.605 \\
\hline & & $(9.322)$ & $(1.175)$ & $(0.127)$ & $(0.542)$ & $(0.413)$ & $(1.421)$ & $(0.583)$ \\
\hline$s$ & & -1.041 & -0.471 & 0.414 & 0.527 & 0.142 & 0.487 & -0.474 \\
\hline & & (7.917) & $(0.320)$ & $(0.762)$ & $(0.474)$ & $(0.3$ & $(1.180)$ & $(0.504)$ \\
\hline trade & & $4.129 *$ & 0.130 & 0.041 & 0.261 & $-0.264 * * *$ & 0.198 & -0.008 \\
\hline & & $(2.224)$ & $(0.090)$ & $(0.029)$ & $(1.048)$ & $(0.097)$ & $(0.328)$ & $(0.141)$ \\
\hline$\pi$ & & -0.502 & -0.050 & 0.015 & -0.025 & -2.093 & -0.078 & 0.433 \\
\hline & & $(2.168)$ & $(0.089)$ & $(0.030)$ & $(0.130)$ & $(1.415)$ & $(0.329)$ & $(0.315)$ \\
\hline inst & & $-1.492 *$ & -0.029 & 0.000 & -0.033 & 0.028 & -0.402 & $0.094 *$ \\
\hline & & $(0.827)$ & $(0.033)$ & $(0.011)$ & $(0.049)$ & $(0.036)$ & $(0.870)$ & $(0.052)$ \\
\hline credit & & $-4.753^{* *}$ & $-0.277 * * *$ & -0.020 & 0.063 & $0.183^{*}$ & -0.208 & $-2.832 * * *$ \\
\hline & & $(2.254)$ & $(0.092)$ & $(0.031)$ & $(0.133)$ & $(0.101)$ & $(0.343)$ & $(0.870)$ \\
\hline $\log n$ & & $\begin{array}{c}-8.935 \\
(6.054)\end{array}$ & $\begin{array}{c}-0.036 \\
(0.259)\end{array}$ & $\begin{array}{c}-0.143 * * \\
(0.064)\end{array}$ & $\begin{array}{c}-0.273 \\
(0.272)\end{array}$ & $\begin{array}{c}-0.456^{* *} \\
(0.211)\end{array}$ & $\begin{array}{l}-1.962 * * * \\
(0.752)\end{array}$ & $-1.051 * * *$ \\
\hline $\log \left(g_{n}+g_{y}+\delta\right)$ & & -7.110 & 0.292 & $-0.186^{* *}$ & 0.175 & $0.758 * *$ & $1.871^{*}$ & -0.134 \\
\hline & & $(7.173)$ & $(0.292)$ & $(0.092)$ & $(0.402)$ & $(0.304)$ & $(1.030)$ & $(0.430)$ \\
\hline $\log$ rem $_{t-1} / y_{t-l}$ & & 2.946 & 0.011 & 0.005 & $0.081 * * *$ & $-0.104 * * *$ & $-0.104 * *$ & -0.007 \\
\hline & & (1.991) & $(0.013)$ & $(0.004)$ & $(0.018)$ & $(0.013)$ & $(0.044)$ & $(0.019)$ \\
\hline $\log (\mathrm{rem} / \mathrm{y})^{G E O}$ & & $-17.592 * *$ & 0.048 & 0.015 & 0.031 & 0.036 & 0.838 & -0.434 \\
\hline & & $(7.753)$ & $(0.250)$ & $(0.080)$ & $(0.371)$ & $(0.267)$ & $(0.925)$ & $(0.374)$ \\
\hline $\log (\mathrm{rem} / \mathrm{y})^{R W}$ & & 4.117 & 0.301 & $-1.392 * * *$ & $3.441 *$ & 0.352 & 1.474 & $-4.965 * *$ \\
\hline & & $(34.206)$ & $(1.361)$ & $(0.461)$ & $(1.974)$ & $(1.508)$ & $(5.026)$ & $(2.109)$ \\
\hline$z \times \log r e m_{t-1} / y_{t-1}$ & & -0.145 & $0.306^{* * * *}$ & -0.015 & $\begin{array}{l}0.144 * * * \\
(0.028)\end{array}$ & $\begin{array}{c}-0.001 \\
(0.002)\end{array}$ & $\begin{array}{c}0.038 \\
(0.027)\end{array}$ & $0.054 * *$ \\
\hline $\mathrm{z} \times \log (\mathrm{rem} / \mathrm{y})^{G E O}$ & & $\begin{array}{l}(0.252) \\
1.082 *\end{array}$ & $0.518^{* * * *}$ & $0.667 * * *$ & $\begin{array}{l}(0.028) \\
0.671 * * *\end{array}$ & $\begin{array}{l}(0.002) \\
0.117\end{array}$ & $0.505 * * *$ & $0.458 * * *$ \\
\hline & & $(0.574)$ & $(0.173)$ & $(0.118)$ & $(0.172)$ & $(0.195)$ & $(0.139)$ & $(0.135)$ \\
\hline$z \times \log (\mathrm{rem} / \mathrm{y})^{R W}$ & & $-3.629 * *$ & $1.097 * * *$ & $1.562 * * *$ & $1.503 * * *$ & $1.641 *$ & $1.039 * * *$ & $0.676^{* *}$ \\
\hline & & $(1.411)$ & $(0.290)$ & $(0.327)$ & $(0.294)$ & $(0.849)$ & $(0.269)$ & $(0.280)$ \\
\hline$F$-stat & & 6.92 & 39.82 & 136.8 & 84.4 & 123.96 & 68.16 & 124.99 \\
\hline
\end{tabular}

Note: Standard errors are in parentheses; $*, * *, * * *$ denotes significance level of $10 \%, 5 \%$ and $1 \%$ respectively. Source: Authors' estimation. 
Table A5

First-stage Regressions for Results in Table 3

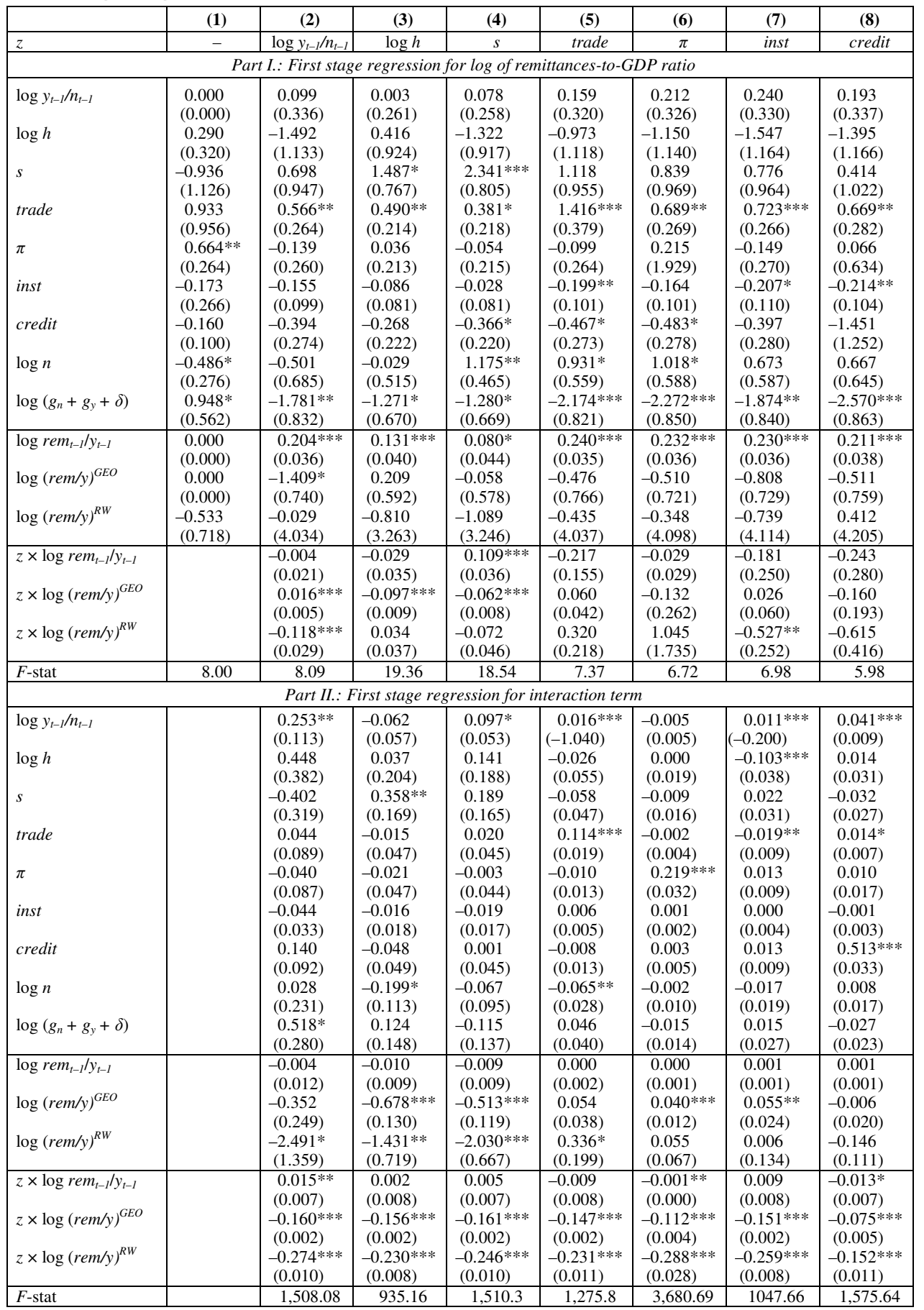

Note: Standard errors are in parentheses; *, **, *** denotes significance level of $10 \%, 5 \%$ and $1 \%$ respectively. Source: Authors' estimation. 